\title{
Return to Earth: A New Mathematical Model of the Earth's Climate
}

\author{
Mulholland Geoscience, Weybridge, Surrey, UK \\ Email address: \\ philip.mulholland@uclmail.net (P. Mulholland) \\ ${ }^{*}$ Corresponding author
}

Stephen Paul Rathbone Wilde, Philip Mulholland*

\section{To cite this article:}

Stephen Paul Rathbone Wilde, Philip Mulholland. Return to Earth: A New Mathematical Model of the Earth's Climate. International Journal of Atmospheric and Oceanic Sciences. Vol. 4, No. 2, 2020, pp. 36-53. doi: 10.11648/j.ijaos.20200402.11

Received: March 21, 2020; Accepted: May 18, 2020; Published: June 8, 2020

\begin{abstract}
In this paper we use the inverse modelling technique, first applied to the atmosphere of the planet Venus, to demonstrate that the process of convective atmospheric mass motion can be invoked to explain the greenhouse effect of the Earth's climate. We propose that the atmospheric cell is the fundamental element of climate, and have developed an alternative climate model based on this process of atmospheric circulation for a hypothetical tidally locked world. The concept of climate derives from studies by the Greek philosopher Aristotle, who identified the three main climatic zones known to the ancient world; the equatorial torrid zone, the polar frigid zone and in between the favoured temperate zone of the Mediterranean world. Aristotle's three climatic zones can be directly linked to the three main atmospheric circulation cells that we now recognise within the Earth's atmosphere. These three cells are the Hadley cell, the Polar cell and the Ferrel cell. Based on the clear association between the traditional Greek concept of climate and the modern meteorological concept of atmospheric circulation cells, we propose that climate be defined as the presence and action of a particular circulation cell type within a given planetary latitudinal zone. We discuss how with knowledge of three simple meteorological parameters of tropopause elevation, tropopause temperature and lapse rate for each atmospheric cell, combined with the measurement of the area of that cell, the average global surface temperature can be calculated. By means of a mathematical model, the Dynamic-Atmosphere EnergyTransport (DAET) climate model we apply an individual climate analysis to each of the three atmospheric cells, and next generate a parallel composite model of the Earth's planetary climate using these data. We apply the concepts and techniques of the adiabatic version of the DAET climate model, and show how this model can be compared with the published NASA image of the Earth's outgoing long-wave radiation recorded by the CERES (Clouds and the Earth's Radiant Energy System) Instrument onboard the NASA Aqua Satellite. Our analysis of the CERES image suggests that the Tibetan plateau forms a permanent geological thermal radiant leak point in the Earth's atmosphere. We also compare the observed temperature found at the maximum elevation of the Antarctic ice cap with the freezing point of super-cooled water, and suggest that there is therefore a temperature controlled and latent heat related upper limit to the vertical development of a continental icecap.
\end{abstract}

Keywords: Atmospheric Cell, Climatology, CERES, Climate Model

\section{Introduction}

The history of Climatology is long and honourable, indeed the very concept of climate goes back to the Greek philosopher Aristotle, who identified the three main types of climatic zone known to the ancient world [1]. These zones are:

A. The Torrid Zone - located to the south of Greece in Africa.

B. The Frigid Zone - located to the far north of Greece where Boreas, the god of the north wind and winter lived.

C. The Temperate Zone of Europe, where the four annual seasons occur, and Greece is most favourably located.

Aristotle's three climatic zones can be directly linked to the three main atmospheric circulation cells that we now recognise within the Earth's atmosphere. These three cells are:

A. The Hadley cell [2], which is a thermal cell, driven by solar radiation from space heating the planet's surface. Two zones of Hadley cells exist in our atmosphere, these are both found in the Tropics and are generally located between the Equator and the Tropic of Cancer in the northern hemisphere and the Tropic of Capricorn in 
the south. The Hadley cell's poleward limit is located in the Horse Latitudes; where a zone of descending air exists forming surface high pressure anticyclones. It is the Hadley cell that is the defining atmospheric feature of Aristotle's Torrid Zone.

B. The Polar cell [3], which is also a thermal cell, but it is driven by atmospheric circulation caused by radiation cooling from the ground surface directly to space. This radiative cooling produces an atmospheric surface inversion, that is most noticeable in winter. The Polar cell's equatorward limit is marked by the Polar Front, an oscillating band with an associated strong horizontal surface temperature gradient; above which is found the jet stream of the upper troposphere. The Polar cell is responsible for the formation and surface export towards the equator of cold dense airmasses. It is the Polar cell that is the defining atmospheric feature of Aristotle's Frigid Zone.

C. The Ferrel cell [4], which is a mechanical cell, located between the Hadley and Polar cells. It acts as a buffer or $\operatorname{cog}$ between the latitudinal limits of the two thermal cells, and has a circulation pattern that abuts and links these two opposing cells. The Ferrel cell forms a zone of mixing and ascending air that is associated with cold cored cyclones. It is the Northern Hemisphere Ferrel cell that accounts for Aristotle's Temperate Zone, with its annual seasonal changes and varied weather patterns.

In this paper we adopt the climate modelling techniques first applied to the planet Venus [5] where we developed an alternative climate model, using the process of atmospheric circulation on a hypothetical tidally locked planet. We use this model to demonstrate that convective atmospheric mass motion recycling can be invoked to explain the planetary greenhouse effect. We use here the modelling strategy of Noonworld and by creating a three-element parallel model constrained to atmospheric data, apply this concept of convective atmospheric mass-motion energy recycling to study the climate of the Earth.

In building a three-element parallel model the primary distinction being studied is between slowly rotating Venus, with its hemisphere encompassing pair of Hadley cells, and rapidly rotating Earth, with its triple cell per hemisphere configuration of Hadley, Polar and Ferrel cells [2-4].

The use of a parallel configuration for the model design addresses the issue that the primary motion of the Earth's atmosphere is predominantly zonal and not meridional flow, and that tropospheric air motion is constrained by the Coriolis effect [6]. This design also addresses a feature of tropical climate best summed up as "Nighttime is the winter of the tropics."

The issue of planetary axial tilt, leading to polar winters dominated by little or no solar flux and summers with no nighttime, was addressed by splitting the polar cell sub-unit in the climate model into two distinctly separate modes of operation. For the summer all convective activity is assumed to recycle the descending air directly back onto a lit arctic surface. By this means the low intensity solar flux inherent at high latitudes is amplified by a process of atmospheric shortcircuiting during the arctic summer. By contrast during the arctic winter the polar sub-cell unit in the model is assumed to have zero solar influx, and all of the power intensity used to drive the atmospheric circulation arrives by advection from the adjacent Ferrel cell.

Finally, we have adopted in the model a nuanced approach to the issue of lapse rate, using a wet adiabatic lapse rate for the Hadley cell, an intermediate environmental lapse rate for the Ferrel cell, and a dry adiabatic lapse rate for the Polar cell. This approach is in contrast to previous work into the study of terrestrial radiation, where a uniform planetary lapse rate of $6^{\circ} \mathrm{C} / \mathrm{km}$ was used across all atmospheric cells [7].

\section{Methodology}

Our modern understanding of the dynamics of the Earth's planetary climate, and the role that radiant energy has in defining the features of the atmospheric circulation system, has progressed with the formulation of the energy budget diagram used to quantify and rank the importance of the constituent elements of the climate system [8]. A key metric of the energy budget is the standard Vacuum Planet or rapidly rotating airless planet equation [9]. This equation is used in Climate Science to calculate the expected thermal emission temperature $T_{e}$ of an illuminated globe under the average solar irradiance that pertains for a planet's average orbital distance from the sun, and for that planet's specific Bond albedo.

"The equilibrium temperature $\mathrm{T}_{\mathrm{e}}$ of an airless, rapidly rotating planet is:

Equation 1: $\mathrm{T}_{\mathrm{e}} \equiv\left[\mathrm{S} \pi \mathrm{R}^{2}(1-\mathrm{A}) / 4 \pi \mathrm{R}^{2} \varepsilon \sigma\right]^{1 / 4}$

where $\sigma$ is the Stefan-Boltzmann Constant, $\varepsilon$ the effective surface emissivity, A the wavelength-integrated Bond albedo, $\mathrm{R}$ the planet's radius (in metres), and $\mathrm{S}$ the solar constant (in Watts $/ \mathrm{m}^{2}$ ) at the planet's average distance from the sun."

The results of applying this Vacuum Planet equation to the Earth are shown in Table 1:

Table 1. The Expected Surface Temperature for an Airless Earth compared with its actual Atmospheric Temperature.

\begin{tabular}{lllll}
\hline Parameter & Symbol & Earth & Units & Dimensions \\
\hline Solar Constant at distance a & $\mathrm{S}$ & 1361 & $\mathrm{~W} / \mathrm{m}^{2}$ & $\mathrm{MT}^{-3}$ \\
Radius of Body & $\mathrm{R}$ & $6,367,445$ & $\mathrm{~m}$ & $\mathrm{~L}$ \\
Bond Albedo & $\mathrm{A}$ & 0.306 & Constant & Constant A \\
Stefan-Boltzmann Constant & $\sigma$ & $5.67 \mathrm{E}-08$ & $\mathrm{~W} / \mathrm{m}^{2} / \mathrm{K}^{4}$ & $\mathrm{MT}^{-3} \mathrm{~K}^{-4}$ \\
Effective surface emissivity & $\varepsilon$ & 1 & Constant & Constant $\varepsilon$ \\
Expected Te & $\mathrm{T}_{\mathrm{e}}$ & 254 & Kelvin & $\mathrm{K}$ \\
Greenhouse Effect & $\mathrm{GE}$ & 34 & Kelvin & $\mathrm{K}$ \\
Actual Ts & $\mathrm{T}_{\mathrm{s}}$ & 288 & Kelvin & $\mathrm{K}$ \\
Distance from the Sun & $\mathrm{a}$ & $1.4960 \mathrm{E}+11 \mathrm{~m}$ & $\mathrm{~L}$ \\
\hline
\end{tabular}

\subsection{Applying the Dynamic-Atmosphere Energy-Transport (DAET) Model to the Study of Earth's Climate}

We are attempting here to simultaneously analyse the energy flows for the Earth's three atmospheric circulation cells, using the adiabatic form of the Dynamic-Atmosphere Energy-Transport (DAET) model, previously used for the study of the climates of Venus and Titan $[5,10]$. The Earth is 
modelled as a spherical globe that cuts a circular silhouette, or disk shadow from the beam of the solar irradiance at the planet's average orbital distance from the Sun. The average fraction of the illumination beam, that the silhouette for each of the three circulation cells intercepts during the course of a year, is latitude dependent.

For the purpose of this analysis it is assumed that the latitudinal reach of the Hadley cell for each hemisphere is from the equator to latitude $30^{\circ}$. The Ferrel cell extends from latitude $30^{\circ}$ to the (ant) arctic circle and the Polar cell occupies the remaining latitudes around the pole of rotation. The tropical Hadley cell of net energy surplus intercepts $60.90 \%$ of the illumination, the temperate mechanical Ferrel cell of energy transport intercepts $36.29 \%$, and the frigid thermal Polar cell of net energy deficit intercepts the remaining $2.81 \%$ of the Sun's energy cut out by the disk silhouette (Figure 1).

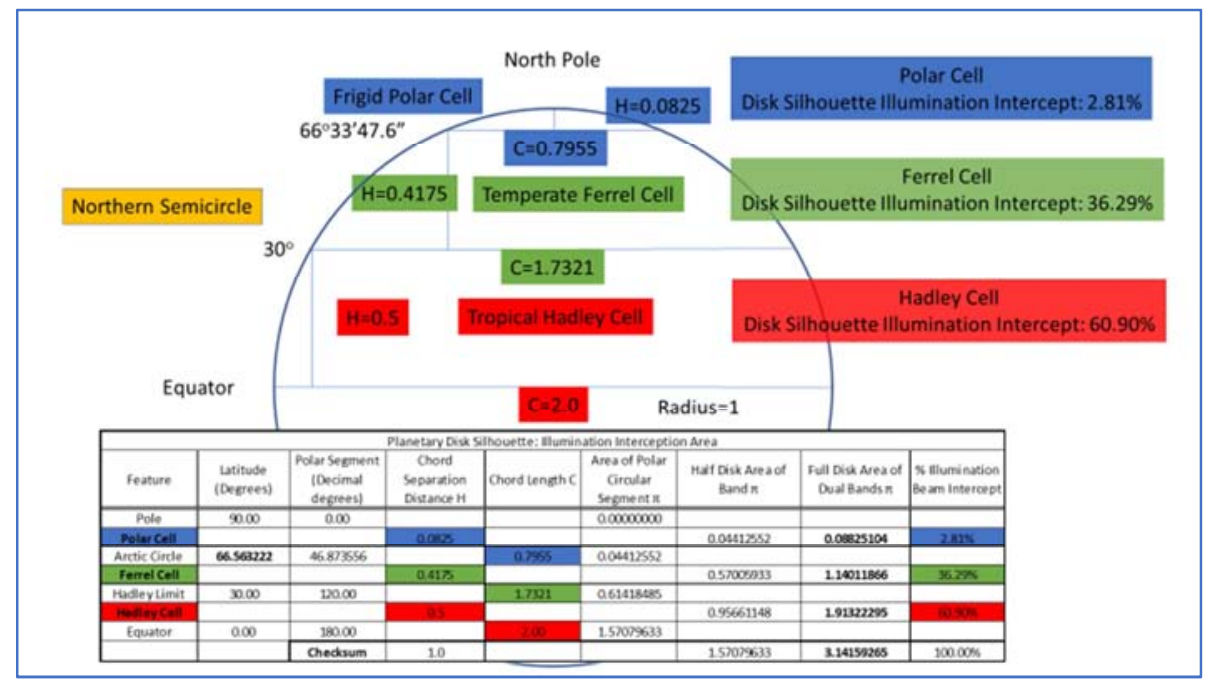

Figure 1. Earth's Planetary Disk Silhouette for the average annual axial tilt of the globe.

The Earth has the form of a globe, and because of this spherical shape the surface of the Earth is unevenly illuminated. The location of the maximum possible power intensity at the surface of the Earth occurs at the solar zenith, the unique point on the Earth's surface where the Sun is directly overhead. At all other locations the slant of the Earth's surface to the sun's beam of light lowers the interception intensity. This is a feature of illumination that we observe at both dawn and dusk when our shadows reach their maximum length as the sunlight grazes the surface of the Earth.

The average power intensity at the Earth's surface is different for each of the three atmospheric cells. The tropical Hadley cells, which occupy $50 \%$ of the surface of the Earth, intercept $60.90 \%$ of the beam silhouette, and therefore receive the highest radiant beam intensity. The Ferrel cells, which occupy $36.29 \%$ of the surface of the Earth, intercept $41.75 \%$ of the beam silhouette and therefore receive a lower radiant beam intensity; while the Polar cells, which occupy $8.25 \%$ of the surface of the Earth, intercept only $2.81 \%$ of the disk silhouette, and therefore receive the lowest average radiant beam power intensity. This quantity of radiant power intensity is defined by the illumination power intensity dilution divisor or "divide by rule" that is specific for each of the three atmospheric cells. This metric is used to constrain the value of the insolation flux used in the modelling process (Figure 2).

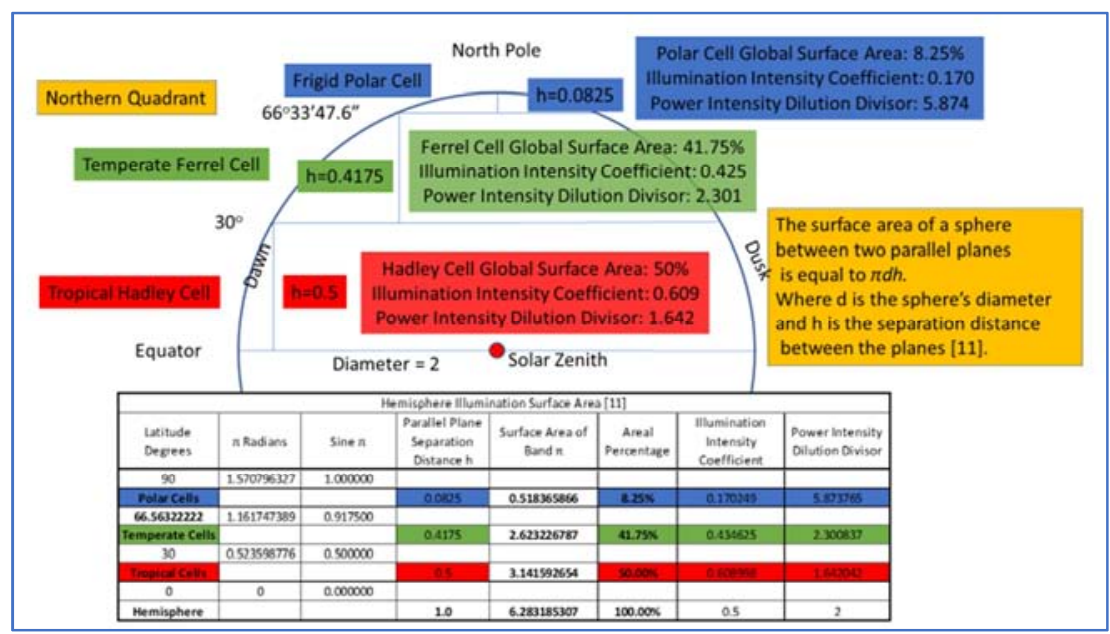

Figure 2. Globular Earth's Lit Hemisphere Illumination Intensity for the average annual surface attitude of the planet [11]. 
The power intensity of the Earth's average annual irradiance is $1361 \mathrm{~W} / \mathrm{m}^{2}$ [12]. This flux which arrives at the Top of the Atmosphere (TOA) is then reduced by the Earth's planetary Bond albedo of 0.306 that acts as a bypass filter diverting radiant solar energy back out to space [12]. It is only the remaining $69.4 \%$ of the radiant flux which is absorbed by the planet, and consequently the value of the solar irradiance that drives the Earth's climate is reduced to a power intensity of $944.53 \mathrm{~W} / \mathrm{m}^{2}$ (Figure 3 ).

It is fundamental to what comes next that the following aspect of power intensity distribution within the Earth's climate system is appreciated in its full subtlety and implications. In figure 1 we observed that the planet intercepts sunlight as if it is a planar disk. However, because of the attitude (slant) of the surface of a sphere with respect to the parallel rays within the solar beam, the strength of the beam striking the surface decreases from its maximum possible post-albedo value of $944.53 \mathrm{~W} / \mathrm{m}^{2}$ at the solar zenith, down to a value of zero at the terminator, the great circle line of dawn and dusk (Figure 3).

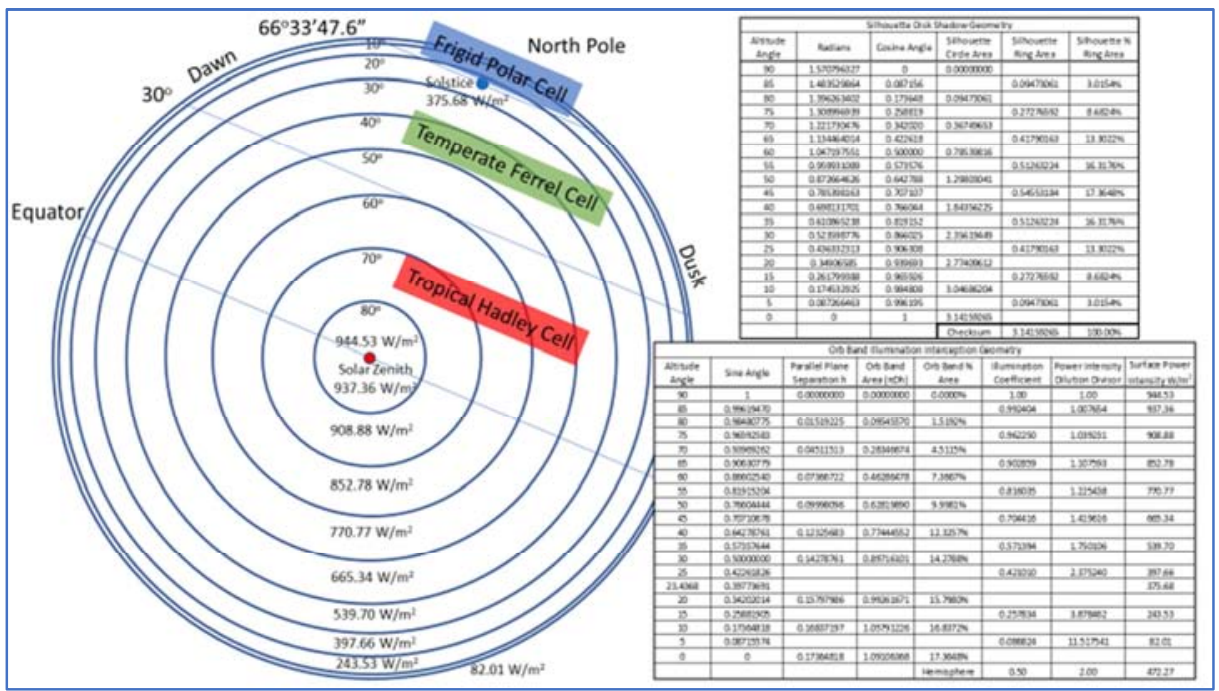

Figure 3. The Scaled Model Globular Earth's Lit Hemisphere Illumination Interception Geometry.

Perhaps the most fundamental issue at the heart of climate modelling is the use of the power intensity illumination divisor of integer 4, that is present in the vacuum planet equation (Equation 1). In this special case divisor 4 is used to dilute the insolation to one quarter of the radiant beam intensity. The original, valid and only purpose of the vacuum planet equation is to establish the radiant exhaust temperature of an illuminated planetary body. Planetary bodies of whatever shape or form are only ever illuminated over the surface of a single hemisphere. So, the appropriate divisor required to calculate the average insolation power intensity for the climate system, supplied by the fully lit face of a planet, is integer 2 .

Furthermore, there will exist on every lit planet a unique location, the solar zenith, at which the radiant power intensity at the base of the atmosphere is exactly equal to the value of the solar irradiance at that planet's orbital distance from the sun (Figure 3). It should again be appreciated that the power intensity illuminating the planet's atmosphere at the solar zenith is scaled down by the Bond albedo which acts as a bypass filter. The albedo filter acts by removing insolation from the climate system, and returning this discarded portion of the high-frequency radiant flux directly back to space.

\subsection{Calculating the Average Surface Temperature of the Earth}

The Earth's atmosphere is a dynamic system composed of three zonally separated and interlocking cells that are symmetrically distributed in each hemisphere (Figure 1). The global areal distribution of each atmospheric cell is shown in Figure 2. The higher percentage of insolation intercepted by the tropical Hadley cells, compared to the low value intercepted by the Polar cells, means that less surface power intensity is delivered to the boreal regions of the planet (Figure 3). The weakened strength of the sunlight in the arctic, caused by the sun's lower angle of elevation in the sky, is a fundamental reason for the lower average surface temperatures found at the poles.

For each atmospheric cell we can compute the average surface temperature if we know the average annual values of the following meteorological parameters:

1. The average height of the tropopause.

2. The average temperature of the tropopause.

3. The average environmental lapse rate of each cell.

Using these three metrics we can then calculate the average surface temperature of each atmospheric circulation cell (Table 2).

Table 2. Atmospheric Cell Parameters.

\begin{tabular}{llll}
\hline Cells & Hadley & Ferrel & Polar \\
\hline Tropopause Height $(\mathrm{km})$ & 17 & 13 & 9 \\
Tropopause Temperature (Celsius) & -83 & -78 & -78.5 \\
Environmental Lapse Rate $(\mathrm{K} / \mathrm{km})$ & 6.5 & 6.5 & 6.5 \\
Average Annual Surface Temperature (Celsius) & 27.9 & 6.5 & -20.0 \\
\hline
\end{tabular}


From our knowledge of the average surface temperature for each atmospheric cell (Table 2) combined with our calculation of the global areal footprint for each cell (Figure 2) we can now calculate the global average surface temperature of the Earth. The key parameters are the global extent of each of the three meteorological cells of Hadley, Ferrel and Polar, and their respective average annual temperatures. By combining these three temperature values and using an area weighted average, the average annual temperature of the whole planet can be derived (Table 3 ).

Table 3. Calculating the Global Average Temperature of the Earth.

\begin{tabular}{llll}
\hline Cell Type & Hadley & Ferrel & Polar \\
\hline Percentage of Global Area & $50.00 \%$ & $41.75 \%$ & $8.25 \%$ \\
Cell Average Temperature (Celsius) & 27.9 & 6.5 & -20.0 \\
Area Weighted Proportion AW\% (Celsius) & 13.94 & 2.71 & -1.65 \\
Average Annual Global Temperature & & & \\
(Celsius) AW\% of Hadley+AW\% of & 15.0 & & \\
Ferrel+AW\% of Polar & & & \\
\hline
\end{tabular}

\subsection{Applying the Dynamic-Atmosphere Energy-Transport (DAET) Climate Model to the Earth}

The Dynamic-Atmosphere Energy-Transport (DAET) climate model contains a mechanism for energy flux recycling using the meteorological process of atmospheric circulation. This model was used to demonstrate that convective atmospheric mass motion can be invoked to explain the planetary greenhouse effect for both Venus and also Titan, the tidally locked moon of Saturn [5, 10]. Atmospheric data for these two bodies show that there is little or no thermal contrast between the lit daytime and the dark nighttime hemispheres on these slowly rotating worlds. Our studies indicate that when applied to slowly rotating Venus, or the moon Titan, the adiabatic model required only a single energy flux partition ratio, common to both the lit and dark sides of each globe, to achieve an appropriate thermal boost within these atmospheres.

However, when a single common energy partition ratio was applied to the process of creating an adiabatic model for the Hadley cell on rapidly rotating Earth, the model failed and created an atmosphere in which the tropopause is higher on the unlit dark side of the globe (Table 6, Attempt 0 ). Clearly this result is in direct contrast to observed atmospheric data, where we find that the convective process on the lit hemisphere produces a tropopause with a higher elevation during the hours of daylight compared to the nighttime. The solution to this failure of the analysis is to apply two distinct and separate energy partition ratios during the process of inverse modelling, one for each side. On the lit side of energy collection, the partition ratio should be biased in favour of the air. However, on the dark side of energy loss, the partition ratio should be biased in favour of the radiant surface of energy loss to space.

The justification for using two distinct energy partition ratios, for the atmospheric circulation cells on rapidly rotating Earth, is based on observation and deduction. The primary observation is that for the Earth atmospheric convection is predominantly a sunlight driven phenomenon. It creates turbulent air motion at the lit surface boundary of the planet, and in the presence of a gravity field turbulent mixing favours energy retention by the air over direct surface radiant energy loss to space.

Contrastingly at night, in the absence of solar radiant loading, the process of surface radiant cooling predominates as the atmosphere stabilises and develops a surface inversion of cold dense air. This near surface vertical thermal profile results in lateral movement of dense air downslope, away from land surface high-elevation points of radiantly efficient emission to space. Consequently, at these locations the overlying air preferentially delivers retained and advected daytime acquired thermal energy down onto the now cooler nighttime surface.

The parameters listed in Table 4 have been used to constrain the adiabatic climate modelling process:

Table 4. Earth Climate Metrics used to constrain the three-element parallel cell DAET climate model.

\begin{tabular}{|c|c|}
\hline \multicolumn{2}{|l|}{ Earth Climate Metrics } \\
\hline Earth's TOA Solar Irradiance W/m ${ }^{2}$ & 1361.0 \\
\hline Earth Bond Albedo & 0.306 \\
\hline Dimmed Intercepted Beam at Solar Zenith W/m² & 944.53 \\
\hline Earth Hemisphere Average Distribution W/m $\mathrm{m}^{2}$ & 472.27 \\
\hline Disk Silhouette of Tropical Hadley Cell & $60.90 \%$ \\
\hline Disk Silhouette of Temperate Ferrel Cell & $36.29 \%$ \\
\hline Disk Silhouette of Frigid Polar Cell & $2.81 \%$ \\
\hline Global Surface Area of Tropical Hadley Cell & $50.00 \%$ \\
\hline Global Surface Area of Temperate Ferrel Cell & $41.75 \%$ \\
\hline Global Surface Area of Frigid Polar Cell & $8.25 \%$ \\
\hline Hadley Cell Power Intensity Dilution Divisor & 1.642042 \\
\hline Ferrel Cell Power Intensity Dilution Divisor & 2.300839 \\
\hline Polar Cell Power Intensity Dilution Divisor & 5.873730 \\
\hline Average Daily Hadley Cell Illumination W/m² & 575.22 \\
\hline Average Daily Ferrel Cell Illumination W/m² & 410.52 \\
\hline Average Daily Polar Cell Illumination W/m² & 160.81 \\
\hline Hadley Annual Surface Temperature (Celsius) & 27.9 \\
\hline Ferrel Annual Surface Temperature (Celsius) & 6.5 \\
\hline Annual Polar Surface Temperature (Celsius) & -20.0 \\
\hline Tropical Wet Lapse Rate $(\mathrm{K} / \mathrm{km})$ & 4.6 \\
\hline Temperate Lapse Rate $(\mathrm{K} / \mathrm{km})$ & 6.5 \\
\hline Frigid Dry Lapse Rate $(\mathrm{K} / \mathrm{km})$ & 8.8 \\
\hline
\end{tabular}

\subsubsection{Modelling the Earth's Hadley Cell}

The two planetary Hadley cells, present in the tropics of the northern and southern hemispheres, together occupy 50\% of the surface area of the Earth (Table 4), and in total intercept $60.90 \%$ of the light that creates the disk silhouette of the planetary beam shadow (Table 4). Because the surface area of the globe's lit hemisphere is twice the cross-sectional area of the total disk silhouette, it follows that the power intensity illumination divisor for the Hadley cells has a value of $\left(0.5^{*} 2\right) / 0.609=1.642$ (Table 4$)$. This divisor is then applied to the post-albedo dimmed irradiance to create the Hadley cell specific power intensity flux of $575.22 \mathrm{~W} / \mathrm{m}^{2}$. This flux is then in turn used to analyse the process of energy recycling within the Earth's Hadley cell by atmospheric mass motion using the adiabatic climate model of the captured solar energy (Table 5). 
Table 5. The inverse modelling process used to determine the dual power intensity flux partition ratios for the Earth's Hadley cell.

\begin{tabular}{|c|c|c|c|c|c|c|c|}
\hline $\begin{array}{l}\text { Cycle } \\
\text { Number }\end{array}$ & $\begin{array}{l}\text { Hadley } \\
\text { Incoming } \\
\text { Captured } \\
\text { Radiation } \\
\end{array}$ & $\begin{array}{l}\text { Heating the } \\
\text { Hadley Cell Lit } \\
\text { side }\end{array}$ & $\begin{array}{l}\text { Lit side Hadley Cell } \\
\text { Radiant Loss to Space }\end{array}$ & $\begin{array}{l}\text { Lit side Hadley Cell } \\
\text { Thermal Export to } \\
\text { Dark Side }\end{array}$ & $\begin{array}{l}\text { Darkside } \\
\text { Hadley Cell } \\
\text { Radiant Loss to } \\
\text { Space }\end{array}$ & $\begin{array}{l}\text { Darkside } \\
\text { Hadley Cell } \\
\text { Thermal Return } \\
\text { to Litside }\end{array}$ & $\begin{array}{l}\text { Radiant Energy } \\
\text { Exiting Tropical } \\
\text { Zone to Space }\end{array}$ \\
\hline & \multicolumn{2}{|c|}{$\begin{array}{l}\text { Annual Temperature } 300.9 \text { Kelvin } \\
(27.9 \mathrm{oC})\end{array}$} & $24.1541 \%$ & $75.8459 \%$ & $53.8273 \%$ & $46.1727 \%$ & \\
\hline 0 & \multicolumn{2}{|l|}{575.22} & & & & \multicolumn{2}{|l|}{0} \\
\hline 1 & 575.2191101 & 575.2191101 & 138.9391858 & 436.2799243 & 234.8378307 & 201.4420936 & 373.7770165 \\
\hline 2 & 575.2191101 & 776.6612037 & 187.5957759 & 589.0654278 & 317.0781865 & 271.9872413 & 504.6739624 \\
\hline 3 & 575.2191101 & 847.2063514 & 204.6353443 & 642.5710071 & 345.8788108 & 296.6921963 & 550.5141551 \\
\hline 4 & 575.2191101 & 871.9113065 & 210.6026119 & 661.3086946 & 355.9648075 & 305.3438871 & 566.5674194 \\
\hline 696 & 575.2191101 & 885.2257096 & 213.8185904 & 671.4071191 & 361.4005197 & 310.0065994 & 575.219110121 \\
\hline 697 & 575.2191101 & 885.2257096 & 213.8185904 & 671.4071191 & 361.4005197 & 310.0065994 & 575.219110121 \\
\hline 698 & 575.2191101 & 885.2257096 & 213.8185904 & 671.4071191 & 361.4005197 & 310.0065994 & 575.219110121 \\
\hline 699 & 575.2191101 & 885.2257096 & 213.8185904 & 671.4071191 & 361.4005197 & 310.0065994 & 575.219110121 \\
\hline 700 & 575.2191101 & 885.2257096 & 213.8185904 & 671.4071191 & 361.4005197 & 310.0065994 & 575.219110121 \\
\hline $\begin{array}{l}\text { Cycle } \\
\text { Number }\end{array}$ & $\begin{array}{l}\text { Proportionate } \\
\text { Hadley Insolation }\end{array}$ & $\begin{array}{l}\text { Heating the } \\
\text { Hadley Cell } \\
\text { Litside }\end{array}$ & $\begin{array}{l}\text { Lit side Hadley Cell } \\
\text { Radiant Loss to Space }\end{array}$ & $\begin{array}{l}\text { Lit side Hadley Cell } \\
\text { Thermal Export to } \\
\text { Dark Side }\end{array}$ & $\begin{array}{l}\text { Darkside Hadley } \\
\text { Cell Radiant } \\
\text { Loss to Space }\end{array}$ & $\begin{array}{l}\text { Darkside Hadley } \\
\text { Cell Thermal } \\
\text { Return to Litside }\end{array}$ & $\begin{array}{l}\text { Radiant Energy } \\
\text { Exiting Tropical } \\
\text { Zone to Space }\end{array}$ \\
\hline Infinity & 575.22 & 885.23 & 213.82 & 671.41 & 361.40 & 310.01 & 575.22 \\
\hline S-B & $5.67 \mathrm{E}-08$ & $5.67 \mathrm{E}-08$ & $5.67 \mathrm{E}-08$ & $5.67 \mathrm{E}-08$ & $5.67 \mathrm{E}-08$ & $5.67 \mathrm{E}-08$ & $5.67 \mathrm{E}-08$ \\
\hline Kelvin & 317.4 & 353.5 & 247.8 & 329.9 & 282.6 & 271.9 & 317.4 \\
\hline \multirow[t]{8}{*}{ Celsius } & 44.4 & 80.5 & -25.2 & 56.9 & 9.6 & -1.1 & 44.4 \\
\hline & Statistic & Mean Exit Temp & Mean Air Temp & Lit-side & Dark-side & Hadley Average & \\
\hline & Kelvin & 265.18 & 300.90 & $\mathrm{~W} / \mathrm{m} 2$ & $\mathrm{~W} / \mathrm{m} 2$ & $\mathrm{~W} / \mathrm{m} 2$ & \\
\hline & Celsius & -7.82 & 27.9 & 885.226 & 671.407 & 778.316 & \\
\hline & \multirow{2}{*}{\multicolumn{2}{|c|}{ Atmospheric Response }} & Thermal Enhancement & Lapse rate & \multicolumn{3}{|c|}{ Tropopause Height $(\mathrm{km})$} \\
\hline & & & (Kelvin) & $\mathrm{K} / \mathrm{Km}$ & Delta K & $\mathrm{Km}$ & \\
\hline & \multirow{2}{*}{\multicolumn{2}{|c|}{$\begin{array}{l}\text { Daytime Hadley Cell } \\
\text { Nighttime Hadley Cell }\end{array}$}} & 36.1 & 4.6 & 82.1 & 18.0 & \\
\hline & & & & 4.6 & 47.3 & 10.4 & \\
\hline
\end{tabular}

The objective of the inverse modelling process used in Table 5 is to establish the daytime convection and nighttime advection pair of energy partition ratios for both of the atmospheric circulation cells. The inverse modelling process is constrained by the two known parameters of annual average temperature and also the average tropopause height for the energy collection (lit side) of each cell. The process of establishing these partition ratios (daytime and nighttime) for the Earth's Hadley cell involved a sequence of tuning that required a "see-saw" approach of iterative "nudges" (Table 6).

Starting with a neutral nighttime energy partition ratio of $50 \%$ radiant loss to space and $50 \%$ thermal retention by the air, the inverse modelling process was run with the objective of establishing the lit surface energy partition ratio that creates a daytime tropopause height of $18 \mathrm{~km}$ (Table 6, Attempt 1). This first attempt resulted in an adiabatic model of the Hadley cell with an average annual temperature of $33.75^{\circ} \mathrm{C}$, which is warmer than the required average temperature of $27.9^{\circ} \mathrm{C}$.
In order to reduce the model temperature to the required value of $27.9^{\circ} \mathrm{C}$ the inverse modelling process was then repeated, but this time adjusting the nighttime energy partition ratio to achieve an increased energy loss to space from the dark side, thereby reducing the average temperature to the required value (Table 6, Attempt 2). This second attempt produced a modelling result in which the daytime tropopause height of $17.8 \mathrm{~km}$ is too low.

This undershoot was then corrected by repeating the search for the lit side energy partition ratio that creates a tropopause height of $18 \mathrm{~km}$ (Table 6, Attempt 3). This third attempt to tune the model by increasing the retention of flux into the air on the lit side produces an average annual temperature of $28.25^{\circ} \mathrm{C}$, which is still too warm.

The fourth attempt, with its increased nighttime radiant loss to space, cools the return flow of air to the lit side sufficiently to successfully achieve both targets of a lit hemisphere tropopause height of $18 \mathrm{~km}$, and an average annual temperature of $27.9^{\circ} \mathrm{C}$ (Table 6 , Attempt 4 ).

Table 6. Establishing the dual set of energy partition ratios for the Earth's Hadley cell.

\begin{tabular}{|c|c|c|c|c|c|c|c|c|c|}
\hline \multirow{2}{*}{$\begin{array}{l}\begin{array}{l}\text { Adiabatic } \\
\text { Nudge }\end{array} \\
\text { Attempt }\end{array}$} & \multicolumn{2}{|c|}{ Lit side of Energy Surplus } & \multicolumn{2}{|c|}{$\begin{array}{l}\text { Dark Side of Energy } \\
\text { Deficit }\end{array}$} & \multirow{2}{*}{$\begin{array}{l}\text { Hadley Average } \\
\text { Air } \\
\text { Temperature }{ }^{\circ} \mathrm{C}\end{array}$} & \multirow{2}{*}{$\begin{array}{l}\text { Hadley Average } \\
\text { Radiant } \\
\text { Temperature }^{\circ} \mathrm{C}\end{array}$} & \multicolumn{2}{|c|}{$\begin{array}{l}\text { Tropopause } \\
\text { Height (km) } \\
\end{array}$} & \multirow{2}{*}{ Comments } \\
\hline & $\begin{array}{l}\text { Loss to } \\
\text { Space }\end{array}$ & $\begin{array}{l}\text { Air } \\
\text { Retention } \\
\end{array}$ & $\begin{array}{l}\text { Loss to } \\
\text { Space }\end{array}$ & $\begin{array}{l}\text { Air } \\
\text { Retention } \\
\end{array}$ & & & Lit Side & $\begin{array}{l}\text { Dark } \\
\text { Side }\end{array}$ & \\
\hline 0 & $37.7351 \%$ & $62.2649 \%$ & $37.7351 \%$ & $62.2649 \%$ & 27.90 & -7.51 & 8.2 & 15.1 & $\begin{array}{l}\text { Single Ratio Adiabatic } \\
\text { Model. Lit side Tropopause is } \\
\text { lower than dark side }\end{array}$ \\
\hline 1 & $24.3854 \%$ & $75.6146 \%$ & $50.0000 \%$ & $50.0000 \%$ & 33.75 & -7.31 & 18.0 & 11.6 & Lit side Tropopause Target 18 \\
\hline
\end{tabular}




\begin{tabular}{|c|c|c|c|c|c|c|c|c|c|}
\hline \multirow{2}{*}{$\begin{array}{l}\begin{array}{l}\text { Adiabatic } \\
\text { Nudge }\end{array} \\
\text { Attempt }\end{array}$} & \multicolumn{2}{|c|}{ Lit side of Energy Surplus } & \multicolumn{2}{|c|}{$\begin{array}{l}\text { Dark Side of Energy } \\
\text { Deficit }\end{array}$} & \multirow{2}{*}{$\begin{array}{l}\text { Hadley Average } \\
\text { Air } \\
\text { Temperature }{ }^{\circ} \mathrm{C}\end{array}$} & \multirow{2}{*}{$\begin{array}{l}\text { Hadley Average } \\
\text { Radiant } \\
\text { Temperature }{ }^{\circ} \mathbf{C}\end{array}$} & \multicolumn{2}{|c|}{$\begin{array}{l}\text { Tropopause } \\
\text { Height (km) }\end{array}$} & \multirow{2}{*}{ Comments } \\
\hline & $\begin{array}{l}\text { Loss to } \\
\text { Space }\end{array}$ & $\begin{array}{l}\text { Air } \\
\text { Retention }\end{array}$ & $\begin{array}{l}\text { Loss to } \\
\text { Space }\end{array}$ & $\begin{array}{l}\text { Air } \\
\text { Retention }\end{array}$ & & & Lit Side & $\begin{array}{l}\text { Dark } \\
\text { Side }\end{array}$ & \\
\hline 2 & $24.3854 \%$ & $75.6146 \%$ & $53.6077 \%$ & $46.3923 \%$ & 27.90 & -7.71 & 17.8 & 10.4 & $\begin{array}{l}\text { km: Hadley is too warm } \\
\text { Target } 27.9^{\circ} \mathrm{C} \text { : Lit side } \\
\text { Tropopause is too low }\end{array}$ \\
\hline 3 & $24.1541 \%$ & $75.8459 \%$ & $53.6077 \%$ & $46.3923 \%$ & 28.25 & -7.79 & 18.0 & 10.4 & $\begin{array}{l}\text { Target } 18 \mathrm{~km} \text { : Hadley is too } \\
\text { warm }\end{array}$ \\
\hline 4 & $24.1541 \%$ & $75.8459 \%$ & $53.8273 \%$ & $46.1727 \%$ & 27.90 & -7.82 & 18.0 & 10.4 & $\begin{array}{l}\text { Both Targets Reached } \\
\text { Successfully }\end{array}$ \\
\hline
\end{tabular}

\subsubsection{Modelling the Earth's Ferrel Cell}

The process of establishing the dual component flux partition ratio for the Ferrel cell adopts the same strategy as that established for the Hadley cell described in Section 2.3.1.

The two planetary Ferrel cells, present in the temperate zones of the northern and southern hemispheres, together occupy $41.75 \%$ of the surface area of the Earth (Table 4) and in total intercept $36.29 \%$ of the light that creates the disk silhouette of the planetary beam shadow (Table 4). Because the surface area of the globe's lit hemisphere is twice the cross-sectional area of the total disk silhouette, it follows that the power intensity illumination divisor for the Ferrel cells has a value of $(0.4175 * 2) / 0.3629=2.3008$ (Table 4$)$. This divisor is then applied to the post-albedo dimmed irradiance to create the Ferrel cell specific power intensity flux of $410.52 \mathrm{~W} / \mathrm{m}^{2}$. This flux is then in turn used to analyse the process of recycling of the captured solar energy by atmospheric mass motion, within the Earth's Ferrel cell using the adiabatic climate model (Table 7).

Table 7. The inverse modelling process used to determine the dual power intensity flux partition ratios for the Earth's Ferrel cell.

\begin{tabular}{|c|c|c|c|c|c|c|c|}
\hline $\begin{array}{l}\text { Cycle } \\
\text { Number }\end{array}$ & $\begin{array}{l}\text { Ferrel Incoming } \\
\text { Captured } \\
\text { Radiation } \\
\end{array}$ & $\begin{array}{l}\text { Heating the Ferrel } \\
\text { Cell Lit side }\end{array}$ & $\begin{array}{l}\text { Ferrel Thermal } \\
\text { Radiation Loss } \\
\text { to Space }\end{array}$ & $\begin{array}{l}\text { Ferrel Cell } \\
\text { Export to Dark } \\
\text { Side }\end{array}$ & $\begin{array}{l}\text { Darkside Ferrel } \\
\text { Cell Radiant } \\
\text { Loss to Space } \\
\end{array}$ & $\begin{array}{l}\text { Darkside Ferrel } \\
\text { Cell Thermal } \\
\text { Return to Litside }\end{array}$ & $\begin{array}{l}\text { Radiant Energy } \\
\text { Exiting Temperate } \\
\text { Zone to Space }\end{array}$ \\
\hline & \multicolumn{2}{|c|}{$\begin{array}{l}\text { Ferrel Partition Ratio: Target Annual } \\
\text { Temperature } 279.5 \text { Kelvin }\left(6.5^{\circ} \mathrm{C}\right)\end{array}$} & $21.6206 \%$ & $78.3794 \%$ & $54.2258 \%$ & $45.7742 \%$ & \\
\hline 0 & \multicolumn{2}{|l|}{410.52} & & & & \multicolumn{2}{|l|}{0} \\
\hline 1 & 410.5171466 & 410.5171466 & 88.7562776 & 321.7608690 & 174.4772691 & 147.2835999 & 263.2335467 \\
\hline 2 & 410.5171466 & 557.8007465 & 120.5998782 & 437.2008683 & 237.0754834 & 200.1253849 & 357.6753616 \\
\hline 3 & 410.5171466 & 610.6425315 & 132.0245901 & 478.6179414 & 259.5342051 & 219.0837363 & 391.5587952 \\
\hline 4 & 410.5171466 & 629.6008829 & 136.1234998 & 493.4773831 & 267.5918499 & 225.8855332 & 403.7153497 \\
\hline 696 & 410.5171466 & 640.2083996 & 138.4169087 & 501.7914909 & 272.1002379 & 229.6912530 & 410.5171466 \\
\hline 697 & 410.5171466 & 640.2083996 & 138.4169087 & 501.7914909 & 272.1002379 & 229.6912530 & 410.5171466 \\
\hline 698 & 410.5171466 & 640.2083996 & 138.4169087 & 501.7914909 & 272.1002379 & 229.6912530 & 410.5171466 \\
\hline 699 & 410.5171466 & 640.2083996 & 138.4169087 & 501.7914909 & 272.1002379 & 229.6912530 & 410.5171466 \\
\hline 700 & 410.5171466 & 640.2083996 & 138.4169087 & 501.7914909 & 272.1002379 & 229.6912530 & 410.5171466 \\
\hline $\begin{array}{l}\text { Cycle } \\
\text { Number }\end{array}$ & $\begin{array}{l}\text { Proportionate } \\
\text { Ferrel Insolation }\end{array}$ & $\begin{array}{l}\text { Boosted Ferrel } \\
\text { Temperature }\end{array}$ & $\begin{array}{l}\text { Ferrel Thermal } \\
\text { Radiation Loss to } \\
\text { Space }\end{array}$ & $\begin{array}{l}\text { Ferrel Cell } \\
\text { Export to Dark } \\
\text { Side }\end{array}$ & $\begin{array}{l}\text { Darkside Ferrel } \\
\text { Cell Radiant Loss } \\
\text { to Space }\end{array}$ & $\begin{array}{l}\text { Darkside Ferrel } \\
\text { Cell Thermal } \\
\text { Return to Litside }\end{array}$ & $\begin{array}{l}\text { Radiant Energy } \\
\text { Exiting Temperate } \\
\text { Zone to Space }\end{array}$ \\
\hline Infinity & 410.517 & 640.208 & 138.417 & 501.791 & 272.100 & 229.691 & 410.517 \\
\hline S-B & 5.67E-08 & 5.67E-08 & 5.67E-08 & 5.67E-08 & 5.67E-08 & 5.67E-08 & $5.67 \mathrm{E}-08$ \\
\hline Kelvin & 291.7 & 326.0 & 222.3 & 306.7 & 263.2 & 252.3 & 291.7 \\
\hline \multirow[t]{8}{*}{ Celsius } & 18.7 & 53.0 & -50.7 & 33.7 & -9.8 & -20.7 & 18.7 \\
\hline & Statistic & Mean Exit Temp & Mean Air Temp & Lit-side & Dark-side & Ferrel Average & \\
\hline & Kelvin & 242.74 & 279.50 & $\mathrm{~W} / \mathrm{m} 2$ & $\mathrm{~W} / \mathrm{m} 2$ & $\mathrm{~W} / \mathrm{m} 2$ & \\
\hline & Celsius & -30.26 & 6.50 & 640.208 & 501.791 & 571.000 & \\
\hline & \multirow{2}{*}{\multicolumn{2}{|c|}{ Atmospheric Response }} & Thermal & Lapse rate & \multicolumn{2}{|c|}{ Tropopause Height (km) } & \\
\hline & & & $\begin{array}{l}\text { Enhancement } \\
\text { (Kelvin) }\end{array}$ & $\mathrm{K} / \mathrm{Km}$ & Delta K & $\mathrm{Km}$ & \\
\hline & \multicolumn{2}{|c|}{ Daytime Ferrel Cell } & 34.3 & 6.5 & 84.4 & 13.0 & \\
\hline & \multicolumn{2}{|c|}{ Nighttime Ferrel Cell } & & 6.5 & 43.5 & 6.7 & \\
\hline
\end{tabular}

As with the Hadley cell model the determination of the parameters for the Ferrel cell starts with a neutral nighttime energy partition ratio of $50 \%$ radiant loss to space and $50 \%$ thermal retention by the air. The inverse modelling process is then run with the objective of establishing the lit surface energy partition ratio that creates a daytime tropopause height of $13 \mathrm{~km}$, for an average annual cell temperature of $6.5^{\circ} \mathrm{C}$. As with the analysis of the Hadley cell, a process of "see-saw" iterations were used to achieve the final pair of partition ratios that satisfy both of these data constraints for the Ferrel cell (Table 8). 
Table 8. Establishing the dual set of energy partition ratios for the Earth's Ferrel cell.

\begin{tabular}{|c|c|c|c|c|c|c|c|c|c|}
\hline \multirow{2}{*}{$\begin{array}{l}\begin{array}{l}\text { Adiabatic } \\
\text { Nudge }\end{array} \\
\text { Attempt }\end{array}$} & \multicolumn{2}{|c|}{$\begin{array}{l}\text { Lit side of Energy } \\
\text { Surplus }\end{array}$} & \multicolumn{2}{|c|}{$\begin{array}{l}\text { Dark Side of Energy } \\
\text { Deficit }\end{array}$} & \multirow{2}{*}{$\begin{array}{l}\text { Ferrel Average } \\
\text { Air } \\
\text { Temperature }{ }^{\circ} \mathbf{C}\end{array}$} & \multirow{2}{*}{$\begin{array}{l}\text { Ferrel Average } \\
\text { Radiant } \\
\text { Temperature }{ }^{\circ} \mathrm{C}\end{array}$} & \multicolumn{2}{|c|}{$\begin{array}{l}\text { Tropopause } \\
\text { Height (km) }\end{array}$} & \multirow{2}{*}{ Comments } \\
\hline & $\begin{array}{l}\text { Loss to } \\
\text { Space }\end{array}$ & $\begin{array}{l}\text { Air } \\
\text { Retention }\end{array}$ & $\begin{array}{l}\text { Loss to } \\
\text { Space }\end{array}$ & $\begin{array}{l}\text { Air } \\
\text { Retention }\end{array}$ & & & $\begin{array}{l}\text { Lit } \\
\text { Side }\end{array}$ & $\begin{array}{l}\text { Dark } \\
\text { Side }\end{array}$ & \\
\hline 0 & $36.7784 \%$ & $63.2216 \%$ & $36.7784 \%$ & $63.2216 \%$ & 6.50 & -28.90 & 5.8 & 10.1 & $\begin{array}{l}\text { Single Ratio Adiabatic Model. } \\
\text { Lit side Tropopause is lower } \\
\text { than dark side }\end{array}$ \\
\hline 1 & $21.9039 \%$ & $78.0961 \%$ & $50.0000 \%$ & $50.0000 \%$ & 12.66 & -29.59 & 13.0 & 7.6 & $\begin{array}{l}\text { Lit side Tropopause Target } 13 \\
\mathrm{~km} \text { : Ferrel is too warm }\end{array}$ \\
\hline 2 & $21.9039 \%$ & $78.0961 \%$ & $53.9690 \%$ & $46.0310 \%$ & 6.50 & -30.11 & 12.8 & 6.7 & $\begin{array}{l}\text { Target } 6.5^{\circ} \mathrm{C} \text { : Lit side } \\
\text { Tropopause is too low }\end{array}$ \\
\hline 3 & $21.6206 \%$ & $78.3794 \%$ & $53.9690 \%$ & $46.0310 \%$ & 6.90 & -30.22 & 13.0 & 6.7 & Target $13 \mathrm{~km}$ : Ferrel is too warm \\
\hline 4 & $21.6206 \%$ & $78.3794 \%$ & $54.2258 \%$ & $45.7742 \%$ & 6.50 & -30.26 & 13.0 & 6.7 & $\begin{array}{l}\text { Both Targets Reached } \\
\text { Successfully }\end{array}$ \\
\hline
\end{tabular}

\subsubsection{Modelling the Earth's Polar Cell}

The two planetary polar cells together occupy $8.25 \%$ of the surface area of the Earth (Table 4 ) and in total intercept only $2.81 \%$ of the light that creates the disk silhouette of the planetary beam shadow (Table 4). As before, because the surface area of the globe's lit hemisphere is twice the cross-sectional area of the total disk silhouette, it follows that the power intensity illumination divisor for the Polar cells has a value of $\left(0.0825^{* 2}\right) / 0.0281=5.874$ (Table 4$)$. When this divisor is applied to the silhouette of the post-albedo dimmed irradiance it creates the Polar cell specific power intensity flux of $160.81 \mathrm{~W} / \mathrm{m}^{2}$.

Modelling tests established that this power intensity can be used to create an average annual Polar cell temperature of minus $20^{\circ} \mathrm{C}$ (Table 9).

Table 9. Testing the model of energy partition ratios for the Earth's Polar cells.

\begin{tabular}{|c|c|c|c|c|c|c|c|c|c|}
\hline \multirow{2}{*}{$\begin{array}{l}\text { Adiabatic } \\
\text { Nudge }\end{array}$} & \multicolumn{2}{|c|}{$\begin{array}{l}\text { Lit side of Energy } \\
\text { Surplus }\end{array}$} & \multicolumn{2}{|c|}{$\begin{array}{l}\text { Dark Side of Energy } \\
\text { Deficit }\end{array}$} & \multirow{2}{*}{$\begin{array}{l}\text { Polar Average Air } \\
\text { Temperature }^{\circ} \mathrm{C}\end{array}$} & \multirow{2}{*}{$\begin{array}{l}\text { Polar Average } \\
\text { Radiant } \\
\text { Temperature }^{\circ} \mathrm{C}\end{array}$} & \multicolumn{2}{|c|}{$\begin{array}{l}\text { Tropopause } \\
\text { Height (km) }\end{array}$} & \multirow{2}{*}{ Comments } \\
\hline & $\begin{array}{l}\text { Loss to } \\
\text { Space }\end{array}$ & $\begin{array}{l}\text { Air } \\
\text { Retention }\end{array}$ & $\begin{array}{l}\text { Loss to } \\
\text { Space } \\
\end{array}$ & $\begin{array}{l}\text { Air } \\
\text { Retention } \\
\end{array}$ & & & $\begin{array}{l}\text { Lit } \\
\text { Side } \\
\end{array}$ & $\begin{array}{l}\text { Dark } \\
\text { Side }\end{array}$ & \\
\hline 0 & $25.5567 \%$ & $74.4433 \%$ & $25.5567 \%$ & $74.4433 \%$ & -20.00 & -79.34 & 7.0 & 8.6 & $\begin{array}{l}\text { Single Ratio Adiabatic } \\
\text { Model. Lit side Tropopause } \\
\text { is lower than dark side }\end{array}$ \\
\hline 1 & $17.9095 \%$ & $82.0905 \%$ & $50.0000 \%$ & $50.0000 \%$ & -42.26 & -81.94 & 9.0 & 4.5 & $\begin{array}{l}\text { Lit side Tropopause Target } \\
9 \mathrm{~km} \text { : Polar is too cold }\end{array}$ \\
\hline 2 & $17.9095 \%$ & $82.0905 \%$ & $34.5138 \%$ & $65.4862 \%$ & -20.00 & -79.89 & 9.6 & 7.1 & $\begin{array}{l}\text { Target }-20^{\circ} \mathrm{C} \text { : Lit side } \\
\text { Tropopause is too high }\end{array}$ \\
\hline 3 & $19.3021 \%$ & $80.6979 \%$ & $34.5138 \%$ & $65.4862 \%$ & -22.31 & -79.55 & 9.0 & 7.0 & $\begin{array}{l}\text { Lit side Tropopause Target } 9 \\
\mathrm{~km} \text { : Polar is too cold }\end{array}$ \\
\hline 4 & $19.3021 \%$ & $80.6979 \%$ & $33.0183 \%$ & $66.9817 \%$ & -20.00 & -79.42 & 9.1 & 7.3 & $\begin{array}{l}\text { Target }-20^{\circ} \mathrm{C} \text { : Lit side } \\
\text { Tropopause is too high }\end{array}$ \\
\hline 5 & $19.4497 \%$ & $80.5503 \%$ & $33.0183 \%$ & $66.9817 \%$ & -20.25 & -79.39 & 9.0 & 7.3 & $\begin{array}{l}\text { Lit side Tropopause Target } \\
9 \mathrm{~km} \text { : Polar is too cold }\end{array}$ \\
\hline 6 & $19.4497 \%$ & $80.5503 \%$ & $32.8566 \%$ & $67.1434 \%$ & -20.00 & -79.37 & 9.0 & 7.3 & $\begin{array}{l}\text { Both Targets Reached } \\
\text { Successfully }\end{array}$ \\
\hline
\end{tabular}

The stable value that results from this initial test, and presented in Table 10 achieves an average annual temperature of minus $20^{\circ} \mathrm{C}$ for the Polar cell. However, the range of minimum average air temperature from minus $7.4^{\circ} \mathrm{C}$ for the summer to minus $32.6^{\circ} \mathrm{C}$ for the winter is actually too small to account for the known winter extrema air temperatures observed in polar regions. For example, air temperatures of lower than minus $50^{\circ} \mathrm{C}$ for July were recorded during advected katabatic drainage storms at the Little America exploration base, on the ice edge of the Ross Sea in Antarctica [13].

Table 10. The inverse modelling process used to test the interlocked dual power intensity flux partition ratios for the Earth's Polar cells.

\begin{tabular}{|c|c|c|c|c|c|c|c|}
\hline $\begin{array}{l}\text { Cycle } \\
\text { Number }\end{array}$ & $\begin{array}{l}\text { Polar Incoming } \\
\text { Captured } \\
\text { Radiation }\end{array}$ & $\begin{array}{l}\text { Heating the } \\
\text { Polar Cell Lit } \\
\text { side }\end{array}$ & $\begin{array}{l}\text { Lit side Polar } \\
\text { Cell Radiant } \\
\text { Loss to Space }\end{array}$ & $\begin{array}{l}\text { Lit side Polar Cell } \\
\text { Thermal Export to } \\
\text { Dark Side }\end{array}$ & $\begin{array}{l}\text { Dark side Polar } \\
\text { Cell Radiant } \\
\text { Loss to Space }\end{array}$ & $\begin{array}{l}\text { Dark side Polar } \\
\text { Cell Thermal } \\
\text { Return to Lit side }\end{array}$ & $\begin{array}{l}\text { Radiant Energy } \\
\text { Exiting Polar } \\
\text { Zone to Space }\end{array}$ \\
\hline & \multicolumn{2}{|c|}{$\begin{array}{l}\text { Polar Partition Ratio: Target Annual } \\
\text { Temperature } 253 \text { Kelvin }\left(-20^{\circ} \mathrm{C}\right)\end{array}$} & $19.4497 \%$ & $80.5503 \%$ & $32.8566 \%$ & $67.1434 \%$ & \\
\hline 0 & 160.81 & & & & & 0 & \\
\hline 1 & 160.8064999 & 160.8064999 & 31.27644873 & 129.5300512 & 42.55911054 & 86.97094068 & 73.83555927 \\
\hline 2 & 160.8064999 & 247.7774406 & 48.19207196 & 199.5853687 & 65.57687337 & 134.0084953 & 113.7689453 \\
\hline 3 & 160.8064999 & 294.8149952 & 57.34075479 & 237.4742404 & 78.02585079 & 159.4483896 & 135.3666056 \\
\hline 4 & 160.8064999 & 320.2548896 & 62.28874851 & 257.9661411 & 84.75878308 & 173.2073580 & 147.0475316 \\
\hline 696 & 160.8064999 & 350.2205534 & 68.11699269 & 282.1035607 & 92.68950726 & 189.4140534 & 160.8064999 \\
\hline
\end{tabular}




\begin{tabular}{|c|c|c|c|c|c|c|c|}
\hline $\begin{array}{l}\text { Cycle } \\
\text { Number }\end{array}$ & $\begin{array}{l}\text { Polar Incoming } \\
\text { Captured } \\
\text { Radiation }\end{array}$ & $\begin{array}{l}\text { Heating the } \\
\text { Polar Cell Lit } \\
\text { side }\end{array}$ & $\begin{array}{l}\text { Lit side Polar } \\
\text { Cell Radiant } \\
\text { Loss to Space }\end{array}$ & $\begin{array}{l}\text { Lit side Polar Cell } \\
\text { Thermal Export to } \\
\text { Dark Side }\end{array}$ & $\begin{array}{l}\text { Dark side Polar } \\
\text { Cell Radiant } \\
\text { Loss to Space }\end{array}$ & $\begin{array}{l}\text { Dark side Polar } \\
\text { Cell Thermal } \\
\text { Return to Lit side }\end{array}$ & $\begin{array}{l}\text { Radiant Energy } \\
\text { Exiting Polar } \\
\text { Zone to Space }\end{array}$ \\
\hline 697 & 160.8064999 & 350.2205534 & 68.11699269 & 282.1035607 & 92.68950726 & 189.4140534 & 160.8064999 \\
\hline 698 & 160.8064999 & 350.2205534 & 68.11699269 & 282.1035607 & 92.68950726 & 189.4140534 & 160.8064999 \\
\hline 699 & 160.8064999 & 350.2205534 & 68.11699269 & 282.1035607 & 92.68950726 & 189.4140534 & 160.8064999 \\
\hline 700 & 160.8064999 & 350.2205534 & 68.11699269 & 282.1035607 & 92.68950726 & 189.4140534 & 160.8064999 \\
\hline $\begin{array}{l}\text { Cycle } \\
\text { Number }\end{array}$ & $\begin{array}{l}\text { Proportionate Polar } \\
\text { Insolation }\end{array}$ & $\begin{array}{l}\text { Heating the Polar } \\
\text { Cell Lit side }\end{array}$ & $\begin{array}{l}\text { Lit side Polar } \\
\text { Cell Radiant } \\
\text { Loss to Space }\end{array}$ & $\begin{array}{l}\text { Lit side Polar Cell } \\
\text { Thermal Export to } \\
\text { Dark Side }\end{array}$ & $\begin{array}{l}\text { Dark side Polar } \\
\text { Cell Radiant Loss } \\
\text { to Space }\end{array}$ & $\begin{array}{l}\text { Dark side Polar } \\
\text { Cell Thermal } \\
\text { Return to Lit side }\end{array}$ & $\begin{array}{l}\text { Radiant Energy } \\
\text { Exiting Polar } \\
\text { Zone to Space }\end{array}$ \\
\hline Infinity & 160.81 & 350.22 & 68.12 & 282.10 & 92.69 & 189.41 & 160.81 \\
\hline S-B & $5.67 \mathrm{E}-08$ & $5.67 \mathrm{E}-08$ & 5.67E-08 & 5.67E-08 & 5.67E-08 & 5.67E-08 & $5.67 \mathrm{E}-08$ \\
\hline Kelvin & 230.8 & 280.3 & 186.2 & 265.6 & 201.1 & 240.4 & 230.8 \\
\hline \multirow[t]{8}{*}{ Celsius } & -42.2 & 7.3 & -86.8 & -7.4 & -71.9 & -32.6 & -42.2 \\
\hline & Statistic & Mean Exit Temp & Mean Air Temp & Lit side & Dark side & Polar Average & \\
\hline & Kelvin & 193.63 & 253.0 & $\mathrm{~W} / \mathrm{m} 2$ & $\mathrm{~W} / \mathrm{m} 2$ & $\mathrm{~W} / \mathrm{m} 2$ & \\
\hline & Celsius & -79.37 & -20.0 & 350.221 & 282.104 & 316.162 & \\
\hline & & & Thermal & Lapse rate & Tropopause Height & $(\mathrm{km})$ & \\
\hline & \multicolumn{2}{|c|}{ Atmospheric Response } & $\begin{array}{l}\text { Enhancement } \\
\text { (Kelvin) }\end{array}$ & $\mathrm{K} / \mathrm{Km}$ & Delta K & $\mathrm{Km}$ & \\
\hline & \multirow{2}{*}{\multicolumn{2}{|c|}{$\begin{array}{l}\text { Daytime Polar Cell } \\
\text { Night time Polar Cell }\end{array}$}} & 49.6 & 8.8 & 79.4 & 9.0 & \\
\hline & & & & 8.8 & 64.5 & 7.3 & \\
\hline
\end{tabular}

Modern icecap temperature data recorded for Antarctica regularly reach values of minus $70^{\circ} \mathrm{C}$ in winter (Figure 4), and so an alternative modelling strategy was devised to account for these extreme temperature values recorded for winter in polar regions.

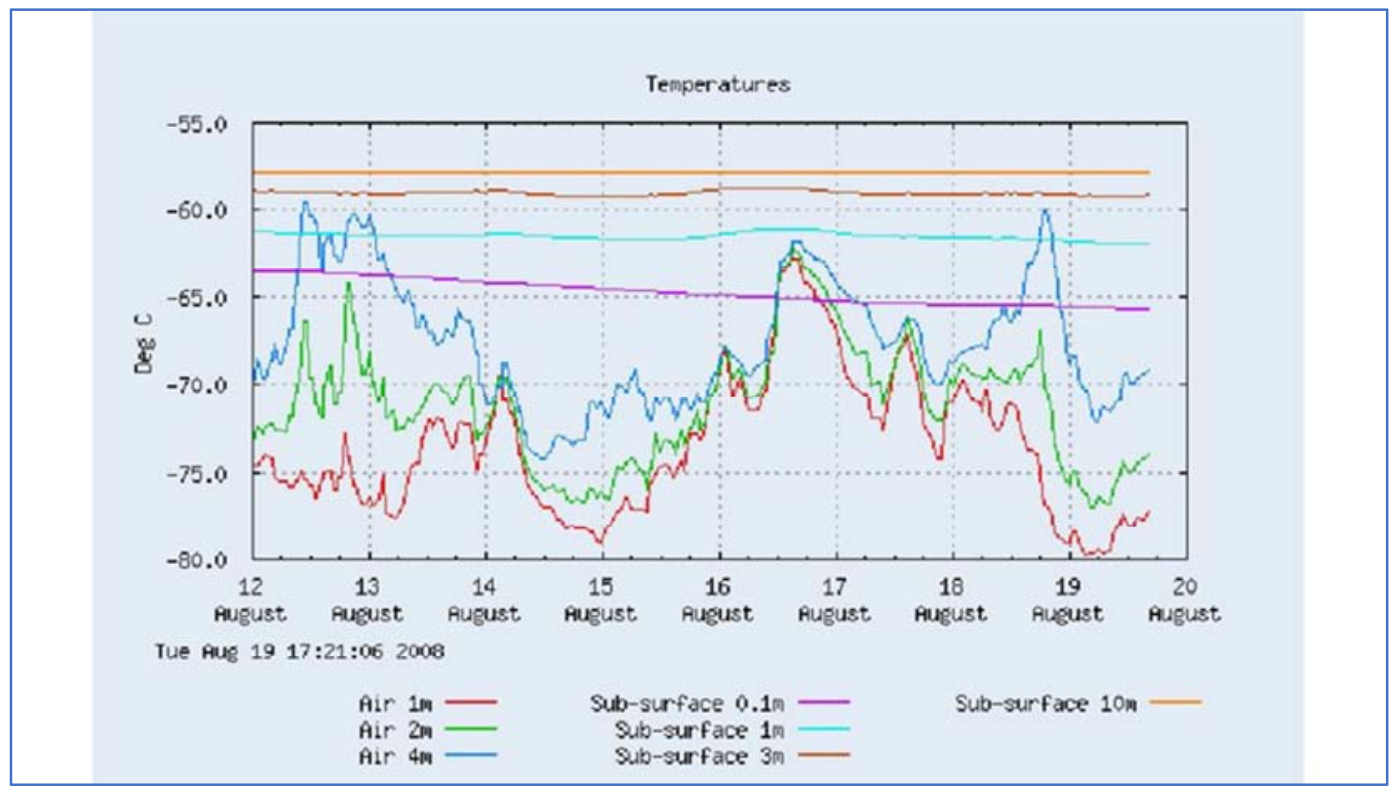

Figure 4. Australian Antarctic Division [14]: Dome Argus Temperature Profile: $12^{\text {th }}-19^{\text {th }}$ August 2008.

The key difference between the polar cells and the two other atmospheric cells present in the Earth's atmosphere, is that in summer the high latitude polar regions experience months of continuous daylight. The effect of continuous daylight is that any atmospheric convective activity, that results in vertical overturning in the Polar cell, returns air back onto a lit surface. This return of air onto the illuminated surface effectively short circuits the surface energy partition process, and delivers an energy flux boost directly back to the lit summer Polar cell environment.

By contrast, during their respective winter season, each Polar cell experiences months of continuous darkness and there is no direct input of radiant solar energy. Consequently, all of the energy flux experienced by the cells throughout the months of continuous darkness is a direct result of advected air transported into the polar environment from the abutting Ferrel cell.

In order to address the dichotomy of continuous summer illumination and continuous winter darkness, the design of the adiabatic model of the Polar cell was altered to incorporate the convective feedback process of summer, and also the advected process of winter into two separate modelling streams. For the purposes of this analysis, and as merely a scoping proposal, the average Polar cell summer temperature is assumed to be plus $5^{\circ} \mathrm{C}$, and the average winter temperature is assumed to be minus $45^{\circ} \mathrm{C}$. These two separate seasonal values combine to create the required average annual temperature for the Polar cell of minus $20^{\circ} \mathrm{C}$ (Table 11 ). 
Table 11. The inverse modelling process used to determine the seasonally separated dual power intensity flux partition ratios for the Earth's Polar cells.

\begin{tabular}{|c|c|c|c|c|c|c|c|c|}
\hline $\begin{array}{l}\text { Cycle } \\
\text { Number }\end{array}$ & $\begin{array}{l}\text { Polar } \\
\text { Incoming } \\
\text { Captured } \\
\text { Radiation } \\
\end{array}$ & $\begin{array}{l}\text { Heating the } \\
\text { Summer } \\
\text { Polar Cell }\end{array}$ & $\begin{array}{l}\text { Summer Polar } \\
\text { Thermal } \\
\text { Radiant Loss to } \\
\text { Space }\end{array}$ & $\begin{array}{l}\text { Summer Polar Cell } \\
\text { Return to Surface }\end{array}$ & $\begin{array}{l}\text { Winter Air } \\
\text { Advected from } \\
\text { Ferrel Cell }\end{array}$ & $\begin{array}{l}\text { Retained in } \\
\text { the Winter } \\
\text { Polar Cell }\end{array}$ & $\begin{array}{l}\text { Winter Polar } \\
\text { Cell Radiant } \\
\text { Loss to Space }\end{array}$ & $\begin{array}{l}\text { Winter Polar } \\
\text { Cell Cold Air } \\
\text { Returned to } \\
\text { Ferrel Cell } \\
\end{array}$ \\
\hline & \multicolumn{2}{|c|}{$\begin{array}{l}\text { Polar Partition Ratio: Target } \\
\text { Summer Temperature } 278 \\
\text { Kelvin }\left(5^{\circ} \mathrm{C}\right)\end{array}$} & $32.1957 \%$ & $67.8043 \%$ & \multicolumn{2}{|c|}{$\begin{array}{l}\text { Polar Partition Ratio: Target } \\
\text { Winter Temperature } 228 \text { Kelvin (- } \\
\left.\left.455^{\circ} \mathrm{C}\right)\right)\end{array}$} & $64.0791 \%$ & $35.9209 \%$ \\
\hline 0 & 160.81 & & & & 273.33 & & & 0 \\
\hline 1 & 160.8064999 & 160.8064999 & 51.7728363 & 109.0336636 & 273.3325458 & 273.3325458 & 175.1490034 & 98.1835424 \\
\hline 2 & 160.8064999 & 269.8401635 & 86.8770269 & 182.9631366 & 273.3325458 & 371.5160883 & 238.0641223 & 133.4519660 \\
\hline 3 & 160.8064999 & 343.7696366 & 110.6791650 & 233.0904716 & 273.3325458 & 406.7845119 & 260.6638065 & 146.1207053 \\
\hline 4 & 160.8064999 & 393.8969716 & 126.8180294 & 267.0789421 & 273.3325458 & 419.4532512 & 268.7818192 & 150.6714320 \\
\hline 696 & 160.8064999 & 499.4652071 & 160.8064999 & 338.6587071 & 273.3325458 & 426.5549856 & 273.3325458 & 153.2224397 \\
\hline 697 & 160.8064999 & 499.4652071 & 160.8064999 & 338.6587071 & 273.3325458 & 426.5549856 & 273.3325458 & 153.2224397 \\
\hline 698 & 160.8064999 & 499.4652071 & 160.8064999 & 338.6587071 & 273.3325458 & 426.5549856 & 273.3325458 & 153.2224397 \\
\hline 699 & 160.8064999 & 499.4652071 & 160.8064999 & 338.6587071 & 273.3325458 & 426.5549856 & 273.3325458 & 153.2224397 \\
\hline 700 & 160.8064999 & 499.4652071 & 160.8064999 & 338.6587071 & 273.3325458 & 426.5549856 & 273.3325458 & 153.2224397 \\
\hline $\begin{array}{l}\text { Cycle } \\
\text { Number }\end{array}$ & $\begin{array}{l}\text { Proportionate } \\
\text { Polar } \\
\text { Insolation }\end{array}$ & $\begin{array}{l}\text { Heating the } \\
\text { Summer Polar } \\
\text { Cell }\end{array}$ & $\begin{array}{l}\text { Summer Polar } \\
\text { Thermal Radiant } \\
\text { Loss to Space }\end{array}$ & $\begin{array}{l}\text { Summer Polar Cell } \\
\text { Return to Surface }\end{array}$ & $\begin{array}{l}\text { Winter Air } \\
\text { Advected from } \\
\text { Ferrel Cell }\end{array}$ & $\begin{array}{l}\text { Retained in } \\
\text { the Winter } \\
\text { Polar Cell }\end{array}$ & $\begin{array}{l}\text { Winter Polar } \\
\text { Cell Radiant } \\
\text { Loss to Space }\end{array}$ & $\begin{array}{l}\text { Winter Polar } \\
\text { Cell Cold Air } \\
\text { Returned to } \\
\text { Ferrel Cell }\end{array}$ \\
\hline Infinity & 160.81 & 499.47 & 160.81 & 338.66 & 273.33 & 426.55 & 273.33 & 153.22 \\
\hline S-B & $5.67 \mathrm{E}-08$ & 5.67E-08 & $5.67 \mathrm{E}-08$ & $5.67 \mathrm{E}-08$ & $5.67 \mathrm{E}-08$ & $5.67 \mathrm{E}-08$ & $5.67 \mathrm{E}-08$ & $5.67 \mathrm{E}-08$ \\
\hline Kelvin & 230.8 & 306.4 & 230.8 & 278.0 & 263.5 & 294.5 & 263.5 & 228.0 \\
\hline \multirow[t]{8}{*}{ Celsius } & -42.2 & 33.4 & -42.2 & 5.0 & -9.5 & 21.5 & -9.5 & -45.0 \\
\hline & & Statistic & Mean Exit Temp & Mean Air Temp & Summer & Winter & Polar Average & \\
\hline & & Kelvin & 247.13 & 253.00 & $\mathrm{~W} / \mathrm{m} 2$ & $\mathrm{~W} / \mathrm{m} 2$ & $\mathrm{~W} / \mathrm{m} 2$ & \\
\hline & & Celsius & -43.61 & -20.00 & 499.465 & 338.659 & 419.062 & \\
\hline & & \multirow{2}{*}{\multicolumn{2}{|c|}{ Atmospheric Response }} & Thermal Enhancement & Lapse rate & Tropopause Hei & $\operatorname{ght}(\mathrm{km})$ & \\
\hline & & & & (Kelvin) & $\mathrm{K} / \mathrm{Km}$ & Delta K & $\mathrm{Km}$ & \\
\hline & & \multicolumn{2}{|c|}{ Summer Polar Cell } & 75.6 & 8.8 & 75.6 & 8.6 & \\
\hline & & \multicolumn{2}{|c|}{ Winter Polar Cell } & 31.0 & 8.8 & 66.5 & 7.5 & \\
\hline
\end{tabular}

We have now completed the individual modelling process for each of the Earth's three atmospheric cells $[15,16]$.

\section{Discussion of the Modelling Results}

The triple-cell parallel adiabatic model of Earth's climate is tuned to produce the expected value of the average annual atmospheric temperature of 288 Kelvin $\left(15^{\circ} \mathrm{C}\right)$ using the previously established method of weighted area to determine the average annual temperature of the Earth (Table 3 ).

The results of the inverse modelling process demonstrate that to achieve a stable average air temperature and also an appropriate cell specific tropopause height, solar energy must be preferentially retained in the climate system by the air that is located over the lit portion of the Earth's surface (Table 12). Retention in favour of the air occurs because convection at the solar heated surface boundary is a turbulent process. In the presence of a gravity field solar heated air ascends by buoyancy displacement which removes it from contact with the ground. Because the solid ground surface of a planet is the primary low-frequency radiator, ascending air becomes decoupled from this surface and so retains its energy internally as it rises.

Thermal radiant exhaust of energy to space is the primary control on the ambient atmospheric temperature. Even under conditions of reduced atmospheric opacity, the ground surface radiator of the Earth continues to operate through the Infrared Window, first identified in 1928 as a critical component of atmospheric radiant energy transmission [7].

Under conditions of zero solar radiant loading, either at night or during the polar winter, the ground surface radiator continues to operate through the atmospheric infrared window. The nighttime is an environment of energy deficit, gasses are poor absorbers and emitters of radiant thermal energy, so they heat most effectively by contact with the sunlit warmed surface during the day, and cool most effectively by contact with the radiatively cooled ground surface by night.

The Antarctic winter temperature inversion profile (Figure 4) is a direct consequence of thermal equilibrium being established and maintained by the process of surface radiative cooling. This cooling is caused by direct radiative energy loss to space through the dry transparent atmosphere above the high elevation Antarctic icecap. The radiative process results in the development and maintenance of a surface air temperature inversion. Under these conditions the atmosphere delivers energy to the ground surface radiator, and consequently the energy partition ratio for the winter polar cell is heavily weighted in favour of radiant energy loss to space (Table 12). 
Table 12. Results of the inverse modelling process used to establish power intensity flux partition ratios for the Earth's atmospheric cells.

\begin{tabular}{|c|c|c|c|c|c|c|}
\hline \multirow[b]{2}{*}{ Daily Atmospheric Cell } & \multicolumn{2}{|c|}{ Lit side Partition Ratio } & \multirow{2}{*}{$\begin{array}{l}\text { Lit side } \\
\text { Tropopause } \\
\text { Height }(\mathrm{km})\end{array}$} & \multicolumn{2}{|c|}{ Dark side Partition Ratio } & \multirow{2}{*}{$\begin{array}{l}\text { Dark side } \\
\text { Tropopause } \\
\text { Height (km) }\end{array}$} \\
\hline & $\begin{array}{l}\text { Thermal Radiant } \\
\text { Loss to Space }\end{array}$ & $\begin{array}{l}\text { Thermal Export } \\
\text { to Dark Side }\end{array}$ & & $\begin{array}{l}\text { Thermal Radiant } \\
\text { Loss to Space }\end{array}$ & $\begin{array}{l}\text { Thermal Return to } \\
\text { Lit side }\end{array}$ & \\
\hline $\begin{array}{l}\text { Hadley cell: Target Annual } \\
\text { Temperature } 300.9 \text { Kelvin }\left(27.9^{\circ} \mathrm{C}\right)\end{array}$ & $24.1541 \%$ & $75.8459 \%$ & 18.0 & $53.8273 \%$ & $46.1727 \%$ & 10.4 \\
\hline $\begin{array}{l}\text { Ferrel cell: Target Annual } \\
\text { Temperature } 279.5 \text { Kelvin }\left(6.5^{\circ} \mathrm{C}\right)\end{array}$ & $21.6206 \%$ & $78.3794 \%$ & 13.0 & $54.2258 \%$ & $45.7742 \%$ & 6.7 \\
\hline Seasonal Atmospheric Cell & $\begin{array}{l}\text { Summer Polar cell } \\
\text { Thermal Radiant } \\
\text { Loss to Space }\end{array}$ & $\begin{array}{l}\text { Summer Polar cell } \\
\text { Thermal Return to } \\
\text { Surface }\end{array}$ & $\begin{array}{l}\text { Tropopause } \\
\text { Height }(\mathrm{km})\end{array}$ & $\begin{array}{l}\text { Winter Polar Cell } \\
\text { Thermal Radiant } \\
\text { Loss to Space }\end{array}$ & $\begin{array}{l}\text { Winter Polar Cell } \\
\text { Cold Air Returned } \\
\text { to Ferrel Cell }\end{array}$ & $\begin{array}{l}\text { Tropopause } \\
\text { Height }(\mathrm{km})\end{array}$ \\
\hline $\begin{array}{l}\text { Polar cell: Target Summer } \\
\text { Temperature } 278 \text { Kelvin }\left(5^{\circ} \mathrm{C}\right)\end{array}$ & $32.1957 \%$ & $67.8043 \%$ & 8.6 & & & \\
\hline $\begin{array}{l}\text { Polar cell: Target Winter } \\
\text { Temperature } 228 \text { Kelvin }\left(-45^{\circ} \mathrm{C}\right)\end{array}$ & & & & $64.0791 \%$ & $35.9209 \%$ & 7.5 \\
\hline
\end{tabular}

\subsection{Studying the Effects of Energy Flux Variations Within the Adiabatic DAET Model}

In conducting the modelling analysis presented here the key question that must be addressed is this. What is the justification for using energy partition ratio as the basis for determining the average annual temperature of the Earth?

There are three fundamental physical parameters that underpin our DAET modelling process that relate directly to planetary climate, these are: -

1. Global Atmospheric Temperature.

2. Global Atmospheric Pressure.

3. Global Atmospheric Volume.

We have already demonstrated that if we know the areal weighting of the three atmospheric cells, their respective tropopause heights, their TOA temperatures and also respective lapse rates, then the global average temperature of the planetary atmosphere can be calculated. We also know that the average pressure of the atmosphere can be determined by measurement and is common across all three cells, so the remaining issue is the determination of the planetary atmospheric volume.

If we assume that the tropopause is a pressure related phenomenon, and that the $100 \mathrm{mb}$ pressure marks the upper limit of the troposphere [17], then the question of applying
Boyle's Law to the total planetary atmosphere potentially has merit and requires investigation. The key objection that the Boyle's Law relationship relates only to a confined volume of gas assumes that planetary atmospheres are completely unconfined. Clearly this is not strictly true, the total surface area of the Earth does not change, the total mass of the atmosphere, and therefore its pressure is also a fixed quantity.

So, in the presence of a gravity field that binds the atmosphere to the planet it follows that the volume change we observe associated with a change in tropospheric height for each atmospheric cell must be related to the temperature of that cell. Consequently, we can study the planetary atmosphere in total by treating it as a single gravity confined entity with measurable parameters of temperature, pressure and volume.

In order to test the relationship between atmospheric temperature, pressure and volume, a simple single hemisphere adiabatic model was created with an illumination intensity dilution divisor of integer 2 . This model is assumed to have simple diabatic radiative cooling from the dark unlit hemisphere, and so a constant partition ratio of $50 \%$ radiant energy loss to space and $50 \%$ retention by the air was applied to this part of the model (Table 13).

Table 13. Testing the Whole Earth PVT Adiabatic Model.

\begin{tabular}{|c|c|c|c|c|c|c|c|}
\hline $\begin{array}{l}\text { Cycle } \\
\text { Number }\end{array}$ & $\begin{array}{l}\text { Incoming Captured } \\
\text { Radiation }\end{array}$ & $\begin{array}{l}\text { Heating the Lit } \\
\text { side }\end{array}$ & $\begin{array}{l}\text { Lit side Radiant } \\
\text { Loss to Space }\end{array}$ & $\begin{array}{l}\text { Lit side Thermal } \\
\text { Export to Dark } \\
\text { Side }\end{array}$ & $\begin{array}{l}\text { Darkside } \\
\text { Radiant Loss } \\
\text { to Space } \\
\end{array}$ & $\begin{array}{l}\text { Darkside Thermal } \\
\text { Return to Litside }\end{array}$ & $\begin{array}{l}\text { Radiant Energy } \\
\text { Exiting to Space }\end{array}$ \\
\hline & \multicolumn{2}{|c|}{$\begin{array}{l}\text { Litside Variable Partition Ratio: Target } \\
\text { Annual Temperature } 288 \text { Kelvin }\left(15^{\circ} \mathrm{C}\right)\end{array}$} & $26.9553 \%$ & $73.0447 \%$ & $50.0000 \%$ & $50.0000 \%$ & \\
\hline 0 & 472.267 & & & & & 0 & \\
\hline 1 & 472.267 & 472.267 & 127.3008921 & 344.9661079 & 172.483054 & 172.483054 & 299.783946 \\
\hline 2 & 472.267 & 644.750054 & 173.7941822 & 470.9558718 & 235.4779359 & 235.4779359 & 409.2721181 \\
\hline 3 & 472.267 & 707.7449359 & 190.774629 & 516.9703069 & 258.4851535 & 258.4851535 & 449.2597824 \\
\hline 4 & 472.267 & 730.7521535 & 196.9762889 & 533.7758646 & 266.8879323 & 266.8879323 & 463.8642212 \\
\hline 2996 & 472.267 & 743.990 & 200.5444627 & 543.4450745 & 271.7225373 & 271.7225373 & 472.267 \\
\hline 2997 & 472.267 & 743.9895373 & 200.5444627 & 543.4450745 & 271.7225373 & 271.7225373 & 472.267 \\
\hline 2998 & 472.267 & 743.9895373 & 200.5444627 & 543.4450745 & 271.7225373 & 271.7225373 & 472.267 \\
\hline 2999 & 472.267 & 743.9895373 & 200.5444627 & 543.4450745 & 271.7225373 & 271.7225373 & 472.267 \\
\hline 3000 & 472.267 & 743.990 & 200.5444627 & 543.4450745 & 271.7225373 & 271.7225373 & 472.267 \\
\hline $\begin{array}{l}\text { Cycle } \\
\text { Number }\end{array}$ & $\begin{array}{l}\text { Incoming Captured } \\
\text { Radiation }\end{array}$ & $\begin{array}{l}\text { Heating the Lit } \\
\text { side }\end{array}$ & $\begin{array}{l}\text { Lit side Radiant Loss } \\
\text { to Space }\end{array}$ & $\begin{array}{l}\text { Lit side Thermal } \\
\text { Export to Dark } \\
\text { Side }\end{array}$ & $\begin{array}{l}\text { Darkside } \\
\text { Radiant Loss to } \\
\text { Space }\end{array}$ & $\begin{array}{l}\text { Darkside Thermal } \\
\text { Return to Litside }\end{array}$ & $\begin{array}{l}\text { Radiant Energy } \\
\text { Exiting to Space }\end{array}$ \\
\hline
\end{tabular}




\begin{tabular}{|c|c|c|c|c|c|c|c|}
\hline $\begin{array}{l}\text { Cycle } \\
\text { Number }\end{array}$ & $\begin{array}{l}\text { Incoming Captured } \\
\text { Radiation }\end{array}$ & $\begin{array}{l}\text { Heating the Lit } \\
\text { side }\end{array}$ & $\begin{array}{l}\text { Lit side Radiant } \\
\text { Loss to Space }\end{array}$ & $\begin{array}{l}\text { Lit side Thermal } \\
\text { Export to Dark } \\
\text { Side }\end{array}$ & $\begin{array}{l}\text { Darkside } \\
\text { Radiant Loss } \\
\text { to Space }\end{array}$ & $\begin{array}{l}\text { Darkside Thermal } \\
\text { Return to Litside }\end{array}$ & $\begin{array}{l}\text { Radiant Energy } \\
\text { Exiting to Space }\end{array}$ \\
\hline Infinity & 472.27 & 743.99 & 200.54 & 543.45 & 271.72 & 271.72 & 472.27 \\
\hline S-B & $5.67 \mathrm{E}-08$ & $5.67 \mathrm{E}-08$ & $5.67 \mathrm{E}-08$ & $5.67 \mathrm{E}-08$ & $5.67 \mathrm{E}-08$ & $5.67 \mathrm{E}-08$ & $5.67 \mathrm{E}-08$ \\
\hline Kelvin & 302.1 & 338.5 & 243.9 & 312.9 & 263.1 & 263.1 & 302.1 \\
\hline \multirow[t]{8}{*}{ Celsius } & 29.1 & 65.5 & -29.1 & 39.9 & -9.9 & -9.9 & 29.1 \\
\hline & Statistic & Mean Exit Temp & Mean Air Temp & Lit-side & Dark-side & Hadley Average & \\
\hline & Kelvin & 253.49 & 288.00 & $\mathrm{~W} / \mathrm{m}^{2}$ & $\mathrm{~W} / \mathrm{m}^{2}$ & $\mathrm{~W} / \mathrm{m}^{2}$ & \\
\hline & Celsius & -19.51 & 15.0 & 743.990 & 543.445 & 643.717 & \\
\hline & \multirow{2}{*}{\multicolumn{2}{|c|}{ Atmospheric Response }} & Thermal Enhancement & Lapse rate & \multicolumn{3}{|c|}{ Tropopause Height (km) } \\
\hline & & & (Kelvin) & $\mathrm{K} / \mathrm{Km}$ & Delta K & $\mathrm{Km}$ & \\
\hline & Lit Hemisphere & & 36.4 & 6.0 & 94.6 & 15.8 & \\
\hline & Dark Hemisphere & & & 6.0 & 49.8 & 8.3 & \\
\hline
\end{tabular}

The energy flux within the model was then adjusted by varying the Bond albedo. For each increment of Albedo related radiant power intensity, the inverse modelling process was run to determine the lit surface energy partition ratio that restored the global atmospheric temperature back to a constant value of $15^{\circ} \mathrm{C}$.

Because we are now adjusting the Bond albedo, the power intensity flux in our simple model varies from a maximum case of $680.5 \mathrm{~W} / \mathrm{m}^{2}[1361 / 2 *(1-0.0)]$ for a totally absorptive Earth $($ albedo $=0.0)$, down to a lower limit of $272.2 \mathrm{~W} / \mathrm{m}^{2}$, $[1361 / 2 *(1-0.60)]$ for a bright reflective Earth (albedo=0.60). The power intensity flux lower limit of $272.2 \mathrm{~W} / \mathrm{m}^{2}$ occurs because below this value it is impossible for the model Earth to maintain an average annual temperature of $15^{\circ} \mathrm{C}$ if its albedo becomes any brighter.

The results of these tests are shown in Figure 5.

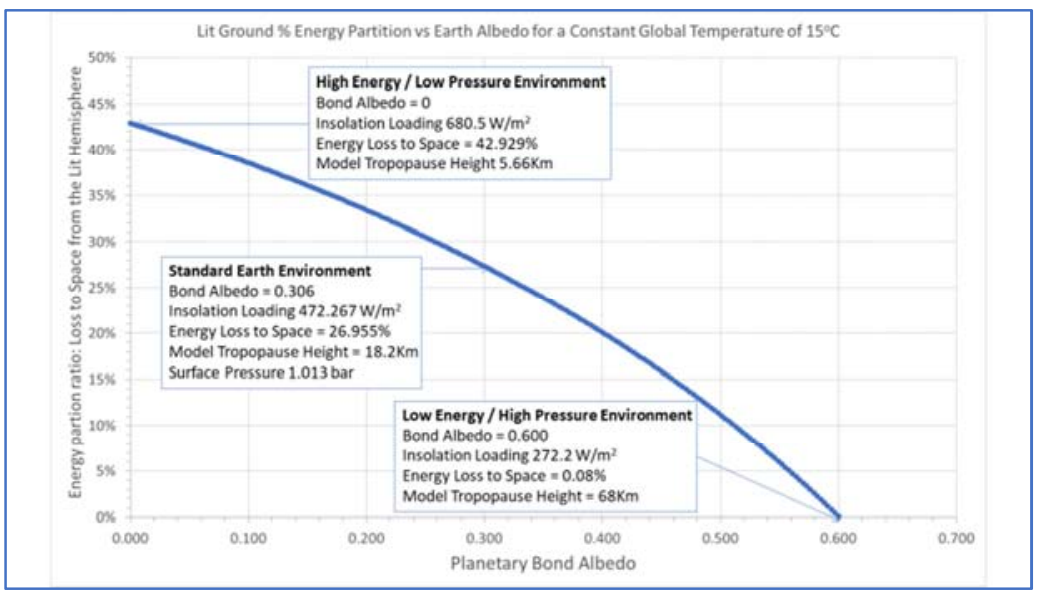

Figure 5. The Variation of Energy Partition Ratio with Power Intensity Influx for a Single Lit Hemisphere Adiabatic Model.

Using data from the American Vacuum Society (AVS) the temperature and pressure profiles for the average atmosphere are shown in Figures 6 and 7 [18]. These data show that for a standard Earth atmosphere and a tropopause defined as occurring at a pressure of 100 mbar (Figure 6) then the average elevation of this pressure is at a height of $16 \mathrm{~km}$ (Figure 7).

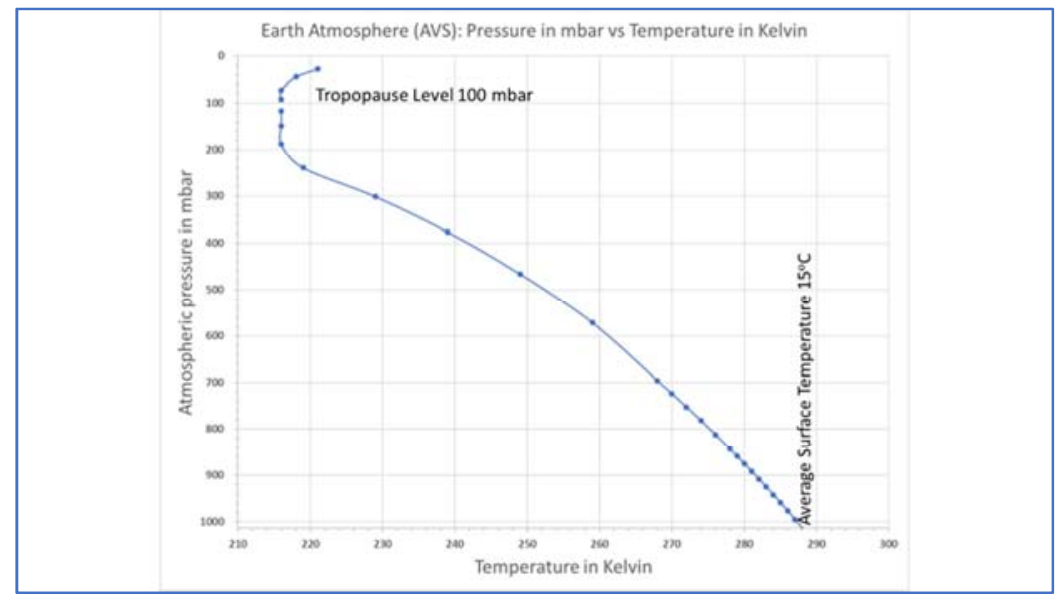

Figure 6. Earth's Average Atmosphere Temperature Profile (AVS data). 


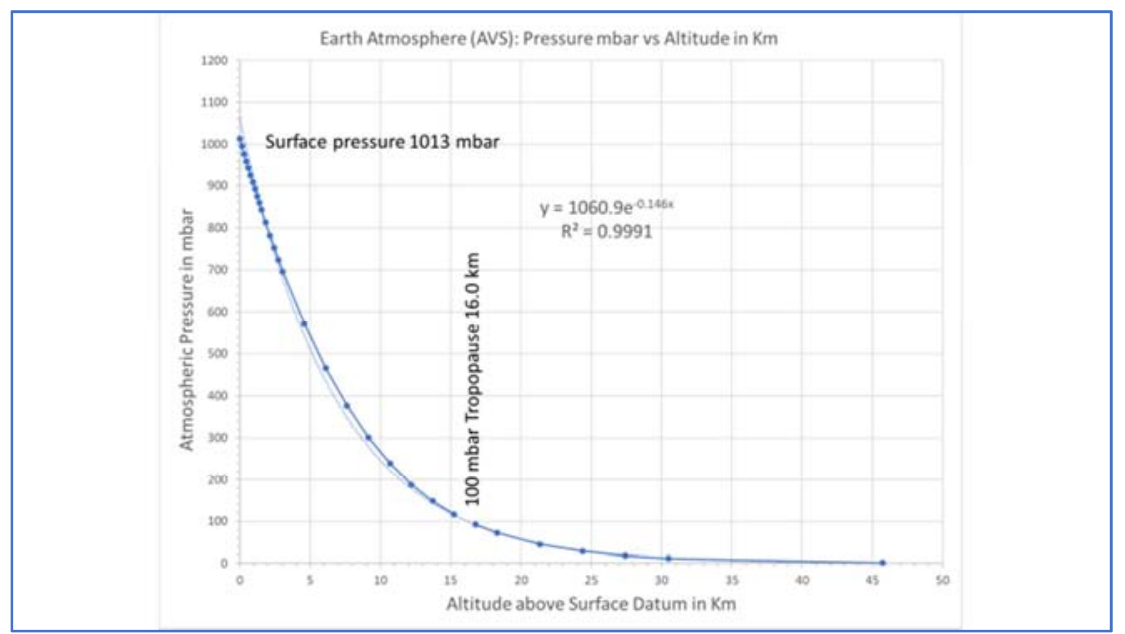

Figure 7. Earth's Average Atmosphere Pressure Profile (AVS data).

Starting with a biased surface datum of minus $50 \mathrm{~km}$, the calculated pressure versus height relationship for the Earth's standard atmosphere (Figure 7) was extended downwards to create a model high pressure atmosphere using an exponential pressure altitude equation (Km versus mbars):-

Equation 2: Pressure $=1060.9 * \mathrm{EXP}(-0.146 * \mathrm{C} 2) \mathrm{mbar}$

Where $\mathrm{C} 2$ is the Datumed Biased Altitude in kilometres.

Equation 2 is constructed to create the standard atmospheric pressure of 1013 mbar at the reference zero altitude of the Earth's surface under current atmospheric conditions. For Equation 2 negative altitudes relate to higher than ambient surface pressure, while positive altitudes relate to lower than ambient pressure. The calculated pressures range from a high pressure state for a model atmosphere thickness of $68 \mathrm{~km}$ (equation biased altitude of minus $50 \mathrm{~km}$ ), down to a low pressure state for a model atmosphere thickness of $5.66 \mathrm{~km}$ (equation biased altitude of plus $13 \mathrm{~km}$ ) (Figure 8).

Using a model specific wet adiabatic lapse rate of 3.8 $\mathrm{K} / \mathrm{km}$ for the lit side of the single cell model, the atmosphere "thickness" records a low of $5.66 \mathrm{~km}$ for the high solar energy input case, with a commensurate balancing high radiant energy loss to space. The maximum value of $68 \mathrm{~km}$ of atmospheric thickness is achieved for the low solar energy input case, and commensurate balancing low radiant energy loss to space (Figure 8). There is therefore a clear relationship between solar energy input and immediate energy shedding to space by the lit surface. This energy shedding is required to maintain the constant modelled average global temperature of $15^{\circ} \mathrm{C}$, and is a pressure dependent effect (Figure 8).

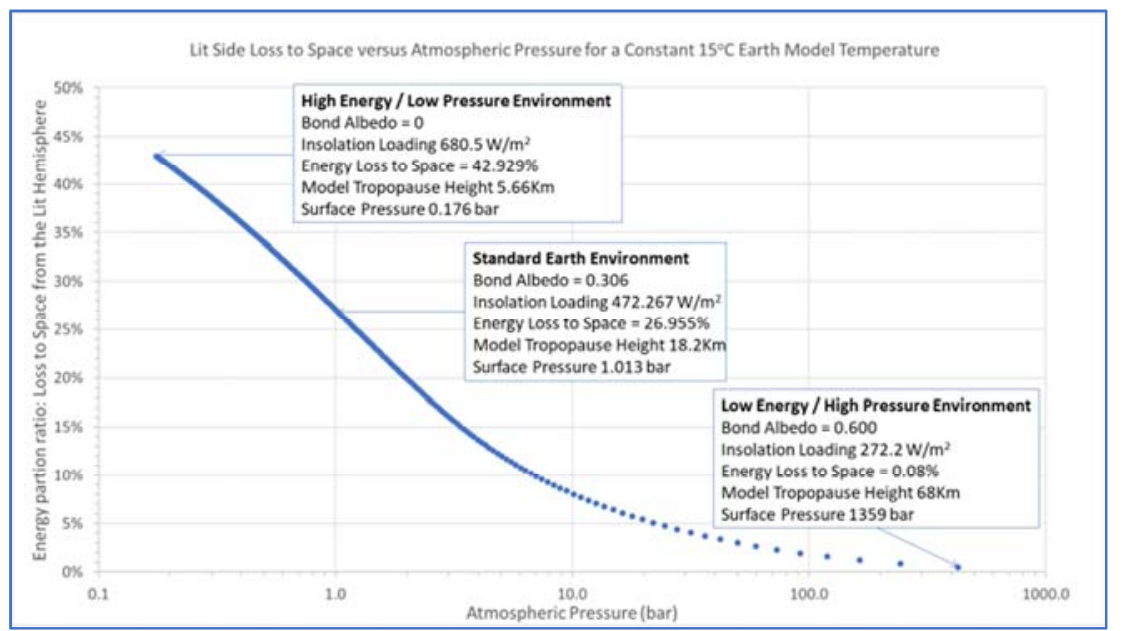

Figure 8. Lit Ground \% Energy Partition vs Surface Atmospheric Pressure for a Constant Earth $15^{\circ} \mathrm{C}$.

In Figure 8 we see the effective pressure dependent limits under which an Earth with an average planetary temperature of $15^{\circ} \mathrm{C}$ can exist for a given range of radiant energy loadings at its current orbital distance from the Sun. With the high albedo, (low energy capture) thick atmosphere end-member of the model we are effectively simulating a high pressure, low temperature version of the atmosphere of Venus.

\subsection{The CERES Image of the Earth's Radiant Emission to Space}

Each of the three atmospheric cells that constitute the circulation system of the Earth's atmosphere has a distinct set of meteorological parameters of areal extent, average insolation power intensity flux, average annual temperature 
and adiabatic lapse rate. The following image (Figure 9) shows the Earth's outgoing long-wave radiation recorded by

the CERES (Clouds and the Earth's Radiant Energy System) Instrument onboard the NASA Aqua Satellite [19].

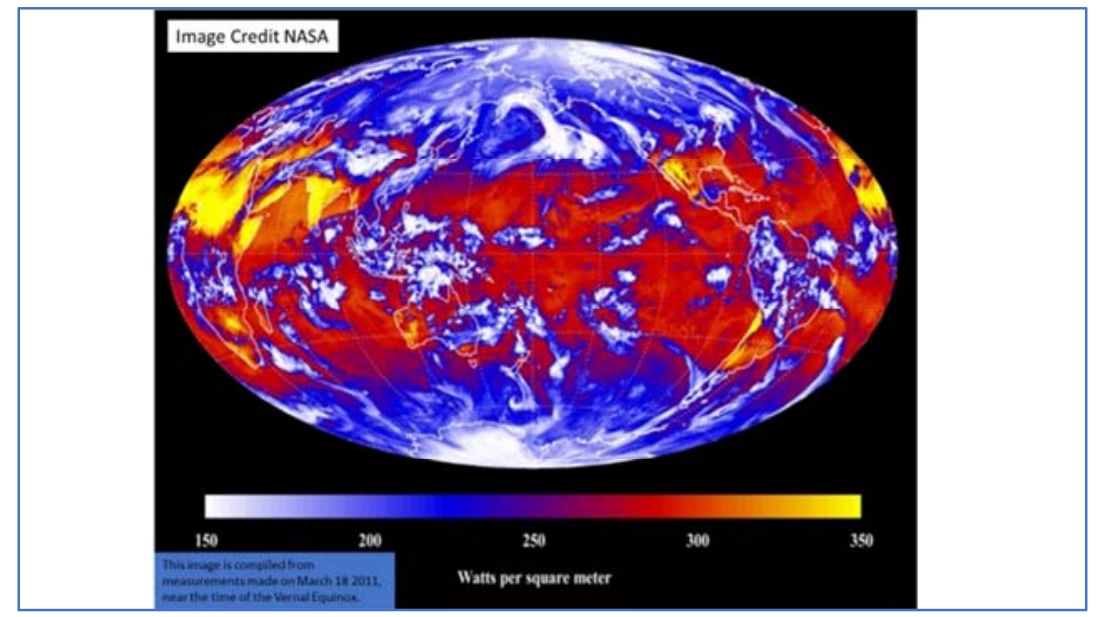

Figure 9. The Earth's outgoing long-wave radiation recorded by the CERES (Clouds and the Earth's Radiant Energy System) Instrument onboard the NASA Aqua Satellite [19, 20].

The colour table legend records the energy flux of the outgoing thermal radiation. This flux ranges from a minimum value of $150 \mathrm{~W} / \mathrm{m}^{2}$ displayed as white, to a maximum flux of $350 \mathrm{~W} / \mathrm{m}^{2}$, displayed as yellow. Using the Stefan-Boltzmann law of radiative emission these energy flux values can be converted to emission temperatures using the following equation: -

Equation 3: $\mathrm{T}=\left(j^{*} / \sigma\right)^{0.25}$

Where $\mathrm{T}$ is the thermodynamic temperature in Kelvin.

$j^{*}$ is the black body radiant emittance in Watts per square metre.

$\sigma$ is the Stefan-Boltzmann constant of proportionality.

(Sigma has a value of $5.670373 * 10^{-8} \mathrm{~W} \mathrm{~m}^{-2} \mathrm{~K}^{-4}$ )

Using equation 3 we can determine that the emission temperatures recorded by the CERES instrument range from a minimum value of 226.8 Kelvin $\left(-46.2^{\circ} \mathrm{C}\right)$ for the 150 $\mathrm{W} / \mathrm{m}^{2}$ low-end flux, to a maximum value of 280.3 Kelvin $\left(7.3^{\circ} \mathrm{C}\right)$ for the $350 \mathrm{~W} / \mathrm{m}^{2}$ high-end flux.

\subsection{Calibrating the CERES Image}

The CERES image (Figure 9) is a single snapshot of the Earth's thermal radiant emission to space. This image contains a significant amount of information, however to understand this in its global context we must first calibrate the image against known measurements of the major components of the Earth's atmospheric system.

Visual inspection of the CERES image (Figure 9) shows the presence of cloud tops associated with the convective storms of the equatorial intertropical convergence zone (ITCZ) or doldrums. These storms are radiating at $150 \mathrm{~W} / \mathrm{m}^{2}$ and have an emission temperature of 227 Kelvin $\left(-46.2^{\circ} \mathrm{C}\right)$. In order to determine the elevation of this emission, we need to use atmospheric parameters for the Hadley, Ferrel and Polar cells established in Section 2.3. (Table 2), which are:

1. The height of the tropopause.

2. The temperature of the tropopause.

3. The environmental lapse rate for each atmospheric cell.

Using the values established in Table 2 we can determine the top down temperature profile for each of the three atmospheric cells.

\subsubsection{Calibrating the Hadley cell}

The calculations for the Hadley cell show that to maintain a $17 \mathrm{~km}$ tropopause with a temperature of 190 Kelvin ($83^{\circ} \mathrm{C}$ ) and a lapse rate of $6.5 \mathrm{~K} / \mathrm{km}$, then the average surface temperature of the tropical zone must be 301 Kelvin $\left(27.9^{\circ} \mathrm{C}\right)$ (Table 14).

Table 14. Hadley Cell - CERES Image Emissions Calibration.

\begin{tabular}{llllll}
\hline $\begin{array}{l}\text { Energy Flux } \\
\text { W/m }\end{array}$ & Kelvin & Celsius & $\begin{array}{l}\text { Hadley Cell } \\
\text { Profile Km }\end{array}$ & $\begin{array}{l}\text { Radiant } \\
\text { Depth Km }\end{array}$ & Hadley Cell Measurements \\
\hline 465 & 301 & 27.9 & 0.00 & & Average Tropical Surface Temperature \\
426 & 294 & 21.4 & 1.00 & & \\
389 & 288 & 14.9 & 2.00 & & \\
350 & 280 & 7.3 & 3.16 & 13.84 & Maximum observed radiant emission depth of the Hadley cell seen from space \\
325 & 275 & 2.1 & 3.96 & 13.04 & \\
309 & 272 & -1.4 & 4.50 & 12.50 & Tibetan Plateau 4500m \\
300 & 270 & -3.3 & 4.80 & 12.20 & \\
275 & 264 & -9.1 & 5.69 & 11.31 & \\
270 & 263 & -10.4 & 5.89 & 11.11 & Height of Kilimanjaro 5892m \\
250 & 258 & -15.3 & 6.64 & 10.36 & Midpoint observed radiant emission depth of the Hadley Cell seen from space \\
225 & 251 & -22.0 & 7.68 & 9.32 & \\
\hline
\end{tabular}




\begin{tabular}{llllll}
\hline $\begin{array}{l}\text { Energy Flux } \\
\text { W/m }\end{array}$ & Kelvin & Celsius & $\begin{array}{l}\text { Hadley Cell } \\
\text { Profile Km }\end{array}$ & $\begin{array}{l}\text { Radiant } \\
\text { Depth Km }\end{array}$ & Hadley Cell Measurements \\
\hline 200 & 244 & -29.3 & 8.80 & 8.20 & Height of Mount Everest $8850 \mathrm{~m}$ \\
175 & 236 & -37.3 & 10.03 & 6.97 & \\
150 & 227 & -46.2 & 11.40 & 5.60 & Maximum supercooled liquid water atmosphere elevation in the Hadley cell \\
140 & 223 & -50.1 & 12.00 & 5.00 & \\
124 & 216 & -56.6 & 13.00 & 4.00 & \\
110 & 210 & -63.1 & 14.00 & 3.00 & \\
97 & 203 & -69.6 & 15.00 & 2.00 & \\
85 & 197 & -76.1 & 16.00 & 1.00 & \\
74 & 190 & -82.6 & 17.00 & 0.00 & Hadley Cell Tropopause Height \\
\hline
\end{tabular}

Converting this average surface temperature of $\sim 28^{\circ} \mathrm{C}$ into a radiant energy emission flux, by using the StefanBoltzmann equation, we can establish that the tropical surface energy flux is $465 \mathrm{~W} / \mathrm{m}^{2}$. This value is $115 \mathrm{~W} / \mathrm{m}^{2}$ higher than the maximum observed flux of $350 \mathrm{~W} / \mathrm{m}^{2}$ in the Ceres image (Figure 9), and so we have established that this image does not record direct sea level surface radiant emission. Rather, with this image we are observing the atmospheric temperatures at elevations of $3,160 \mathrm{~m}(10,370 \mathrm{ft})$ and above. Consequently, all high elevation land surfaces in the latitude zone of $30^{\circ} \mathrm{S}$ to $30^{\circ} \mathrm{N}$, such as the Tibetan plateau at $4,500 \mathrm{~m}(14,750 \mathrm{ft})$, will be capable of directly emitting thermal radiant energy to space through the overlying atmosphere.

\subsubsection{Calibrating the Ferrel cell}

The calculations for the Ferrel cell show that to maintain a $13 \mathrm{~km}$ tropopause with a temperature of $195 \mathrm{Kelvin}\left(-78^{\circ} \mathrm{C}\right)$ and a lapse rate of $6.5 \mathrm{~K} / \mathrm{km}$, then the average annual surface temperature of the temperate zone will be $280 \mathrm{Kelvin}\left(6.5^{\circ} \mathrm{C}\right)$ (Table 15).

Table 15. Ferrel Cell - CERES Image Emissions Calibration

\begin{tabular}{llllll}
\hline $\begin{array}{l}\text { Energy Flux } \\
\text { W/m }\end{array}$ & Kelvin & Celsius & $\begin{array}{l}\text { Ferrel Cell } \\
\text { Profile Km }\end{array}$ & $\begin{array}{l}\text { Radiant } \\
\text { Depth Km }\end{array}$ & Ferrel Cell Measurements \\
\hline 346 & 280 & 6.5 & 0.00 & & Average Temperate Surface Temperature \\
325 & 275 & 2.1 & 0.67 & 11.49 & Maximum observed radiant emission depth of the Ferrel cell seen from space \\
300 & 270 & -3.3 & 1.51 & 10.60 & \\
275 & 264 & -9.1 & 2.40 & 9.64 & \\
250 & 258 & -15.3 & 3.36 & 8.61 & \\
225 & 251 & -22.0 & 4.39 & 7.49 & Height of Denali (Alaska) $6190 \mathrm{~m}$ \\
200 & 244 & -29.3 & 5.51 & 7.00 & Maximum supercooled liquid water elevation in the Ferrel cell \\
190 & 241 & -32.5 & 6.00 & 6.26 & \\
175 & 236 & -37.3 & 6.74 & 4.89 & \\
150 & 227 & -46.2 & 8.11 & 4.00 & \\
135 & 221 & -52.0 & 9.00 & 3.00 & \\
120 & 215 & -58.5 & 10.00 & 2.00 & Ferrel Cell Tropopause Height \\
106 & 208 & -65.0 & 11.00 & 1.00 & \\
93 & 202 & -71.5 & 12.00 & 0.00 & \\
82 & 195 & -78.0 & 13.00 & & \\
\hline
\end{tabular}

Converting this average surface temperature of $6.5^{\circ} \mathrm{C}$ into a radiant energy emission flux, by using the StefanBoltzmann equation, we can now establish that the temperate zone surface energy flux is $346 \mathrm{~W} / \mathrm{m}^{2}$. This value is $46 \mathrm{~W} / \mathrm{m}^{2}$ higher than the maximum observed flux in the CERES image of $300 \mathrm{~W} / \mathrm{m}^{2}$ for the temperate zone as seen from space (Figure 9). Once again, although this image does not record direct sea level surface radiant emission, all land surfaces with an elevation above $1,500 \mathrm{~m}(4,920 \mathrm{ft})$ will be capable of directly emitting thermal radiant energy to space through the overlying atmosphere.

\subsubsection{Calibrating the Polar cell}

The calculations for the Polar cell show that to maintain a $9 \mathrm{~km}$ tropopause with a temperature of 194.5 Kelvin ($78.5^{\circ} \mathrm{C}$ ) and a lapse rate of $6.5 \mathrm{~K} / \mathrm{km}$, then the average annual surface temperature of the polar zone will be 253 Kelvin ($20^{\circ} \mathrm{C}$ ) (Table 16).

Table 16. Polar Cell - CERES Image Emissions Calibration.

\begin{tabular}{llllll}
\hline $\begin{array}{l}\text { Energy Flux } \\
\text { W/m }\end{array}$ & Kelvin & Celsius & $\begin{array}{l}\text { Polar Cell } \\
\text { Profile Km }\end{array}$ & $\begin{array}{l}\text { Radiant Depth } \\
\text { Km }\end{array}$ & Polar Cell Measurements \\
\hline 232 & 253 & -20.0 & 0.00 & & Average Polar Surface Temperature \\
225 & 251 & -22.0 & 0.31 & 8.69 & Maximum observed radiant emission depth of the Polar cell seen from space \\
200 & 244 & -29.3 & 1.43 & 7.57 & \\
175 & 236 & -37.3 & 2.66 & 6.34 & \\
169 & 234 & -39.5 & 3.00 & 6.00 & Elevation of North Dome, Greenland 3000m \\
150 & 227 & -46.2 & 4.03 & 4.97 & Maximum supercooled liquid water elevation in the Polar cell \\
\hline
\end{tabular}




\begin{tabular}{llllll}
\hline $\begin{array}{l}\text { Energy Flux } \\
\text { W/m }\end{array}$ & \multirow{2}{*}{ Kelvin } & Celsius & $\begin{array}{l}\text { Polar Cell } \\
\text { Profile Km }\end{array}$ & $\begin{array}{l}\text { Radiant Depth } \\
\text { Km }\end{array}$ & Polar Cell Measurements \\
\hline 149 & 226 & -46.6 & 4.09 & 4.91 & Elevation of Dome Argus, Antarctica 4093m \\
134 & 221 & -52.5 & 5.00 & 4.00 & \\
119 & 214 & -59.0 & 6.00 & 3.00 & \\
105 & 208 & -65.5 & 7.00 & 2.00 & \\
93 & 201 & -72.0 & 8.00 & 1.00 & Polar Cell Tropopause Height \\
81 & 194.5 & -78.5 & 9.00 & 0.00 & \\
\hline
\end{tabular}

Converting this average surface temperature of $-20^{\circ} \mathrm{C}$ into a radiant energy emission flux, by using the StefanBoltzmann equation, we can now establish that the polar zone surface energy flux is $232 \mathrm{~W} / \mathrm{m}^{2}$. This value is just 7 $\mathrm{W} / \mathrm{m}^{2}$ higher than the maximum observed flux in the CERES image of $225 \mathrm{~W} / \mathrm{m}^{2}$ for the region of the Southern Ocean, south of the Antarctic circle. This calculation demonstrates that all parts of the polar regions above $310 \mathrm{~m}(1,020 \mathrm{ft})$ elevation, and in particular the high elevation ice domes, will be capable of directly emitting thermal radiant energy to space through the overlying atmosphere.

\section{Conclusions and Observations}

1. By creating a dual surface climate model, with one day lit surface of energy surplus and a second dark night surface of energy deficit, we can apply two separate energy partition ratios to these two distinct environments, and study the impacts of these ratios on energy retention and distribution within the DAET climate model.

2. By assuming that the daytime environment on Earth is dominated by adiabatic convection and has an energy partition ratio weighted in favour of the air, we can account for the process of atmospheric uplift and energy retention by the air.

3. By assuming that the night-time environment on Earth is dominated by radiative cooling, and has an energy partition ratio weighted in favour of radiant loss to space, we can account for the standard nighttime air temperature profile, and the development of surface temperature inversions in air.

4. By applying a process of inverse modelling, we can establish the values of the energy partition ratio for the Earth's lit daytime and dark night-time environments. It is this daytime energy retention in favour of the air that creates the climatic thermal enhancement observed on Earth.

5. By using the appropriate adiabatic lapse rate for each cell, our inverse modelling process can be tuned to replicate the expected tropopause height for the Earth's tropical Hadley Cell of energy surplus, that of the temperate Ferrel cell, and also the height for the Earth's Polar Cell of energy deficit.

6. By constructing a simple single lit hemisphere adiabatic model, the range of energy partition ratios required to maintain a constant whole Earth temperature under various solar radiation loadings can be explored. Using an extrapolated pressure altitude equation, the relationship between the energy partition ratio for the lit surface of energy collection and confining atmospheric pressure can be established.

7. Convection efficiency is a pressure related phenomenon. High pressure gaseous environments are more efficient at removing energy from a solar heated surface in the presence of a confining gravity field.

8. Our modelling studies suggest that the opacity of the atmosphere fundamentally controls the height of the radiant emission surface that vents energy to space (as per [17]). However, there is no requirement for opacity to be an atmospheric energy amplifier via radiative feed-back contra [8].

In our analysis of the CERES image (Figure 9) we are looking at climate from a geological perspective. Our motivation for this approach was to try and determine if high elevation solid surfaces, such as the Tibetan Plateau, are "thermally visible" from space, and if the contrast in global land surface elevation between the Cretaceous and the Tertiary Periods can provide a physical explanation for the long-term planetary cooling of the Earth over the last 65 million years.

This analysis is based on the following points: -

1. All planets shed energy to space via thermal radiation.

2. Flexure of solid materials is the fundamental process that interlinks vibrating matter with thermal radiation. The coincidence of the lowest thermal radiant temperature of $-46.2^{\circ} \mathrm{C}$ in the CERES image with the lowest observed temperature of super-cooled water suggests that there is a relationship between planetary Bond albedo and atmospheric thickness (Tables 14, 15, 16). Albedo therefore could be an emergent consequence rather than a cause of planetary climate.

3. Solid surfaces (either rock or ice) held at high elevation are efficient radiators precisely because they are composed of flexible materials.

4. Icecaps can melt, therefore the ice age high elevation solid ice surfaces of Canada and Scandinavia can rapidly disappear with major implications for surface radiation loss, whereas the Tibetan plateau with an elevation of 4,500m remains as a long-term geological high elevation radiant leak point (Table 14).

5. The apparent coincidence between the maximum elevation of the Antarctic Icecap at Dome Argus $(4093 \mathrm{~m})$ and the maximum elevation at which supercooled liquid water can exist in the atmosphere of the Polar cell (4030m) requires further study (Table 16). A possible explanation is that once the ice surface rises above the point where it is no longer possible to have 
supercooled liquid water droplets in the atmosphere, then there is no further possibility for latent heat of crystallisation to be released. Therefore, there is no energy left in the meteorological system to power moist convection, and so vertical ice accumulation stops.

6. On Earth the rapid daily rotation limits the latitudinal reach of the Hadley cell [21, 22], it creates forced descent of upper atmospheric air in the mid-latitudes and directly accounts for the existence of the Ferrel cell. The Ferrel cell is a mechanical cell that acts as a cog between the tropical thermal Hadley cell of solar heating and energy surplus, and the thermal Polar cell of surface radiant cooling and energy deficit.

7. The impact of the forced descent of Hadley cell air in the mid-latitudes can clearly be seen in the CERES image (Figure 9). This descent creates a zone of high surface pressure and reduced moist convection that allows for significant planetary thermal loss to space over continental land areas, such as the Sahara Desert of North Africa. Over the adjacent mid-Atlantic and southern Indian Oceans, the same latitudinal zone of forced air descent allows for clear skies that lead to solar energy capture and retention by the marine waters below.

Our fundamental criticisms of the standard radiative climate model currently used by climate science are as follows: -

First, all materials heat and cool diabatically (laminar exchange of energy through the surface interface), solids do not significantly change their position when they are heated. Gaseous atmospheres not only heat and cool diabatically, but in addition air also heats adiabatically, which is a turbulent motion process of energy acquisition, and is a critical part of daytime surface heating.

Second, it is physically impossible to lose potential energy by radiant thermal emission. Atmospheric adiabatic energy transport is a meteorological process that delivers energy, without any transport loss, to a distant surface that is itself undergoing diabatic cooling by radiant thermal emission to space.

We have designed our climate model to retain the critical dual surface element of a lit globe, namely night and day. The standard climate model is a single surface model that does not include adiabatic energy transfer, because diabatic thermal equilibrium is assumed at all times (both night and day). When in our model we apply the missing element of adiabatic energy transfer from the lit side, by using distinct and separate energy partition ratios for night and day, then the requirement for back radiation greenhouse gas heating is no longer necessary.

We are able to quantify the degree of adiabatic lit surface energy partition in favour of the air by using the process of inverse modelling, a standard geoscience mathematical technique. The issue of atmospheric opacity then becomes a passive process, and the purported atmospheric action of greenhouse heating by back-radiation can be discounted. We believe that our modelling work presented here should lead to a fundamental reassessment of the atmospheric processes relating to energy partition, retention and flow within the Earth's climate system.

\section{References}

[1] Rosenberg, M. 2020 "Temperate, Torrid, and Frigid Zones." ThoughtCo, Feb. 11, 2020 https://www.thoughtco.com/temperate-torrid-and-frigidzones-1435361.

[2] Persson, A. O., 2006. Hadley's principle: understanding and misunderstanding the trade winds. History of meteorology, 3, pp. $17-42$

[3] Qian, W., Wu, K. and Liang, H., 2016. Arctic and Antarctic cells in the troposphere. Theoretical and Applied Climatology, 125 (1-2), pp. 1-12.

[4] Wang, W. L., Wang, Y. and WU, R. S., 2005. A new view on the Ferrel cell. Chinese Journal of Geophysics, 48 (3), pp. 539-545.

[5] Mulholland, P., Wilde, S. P. R., 2020. An Inverse Climate Modelling Study of the Planet Venus. International Journal of Atmospheric and Oceanic Sciences. Vol. 4, No. 1, 2020, pp. 20-35. doi: 10.11648/j.ijaos.20200401.13.

[6] Persson, A. O., 2005. The Coriolis Effect: Four centuries of conflict between common sense and mathematics, Part I: A history to 1885._International Commission on the History of Meteorology 2, $24 \mathrm{pp}$.

[7] Simpson, G. C., 1928. Some Studies in Terrestrial Radiation. Royal Meteorological Society (London) Memoir, Vol II. No. 16, pp. 69-95.

[8] Kiehl, J. T and Trenberth, K. E., 1997. Earth's Annual Global Mean Energy Budget. Bulletin of the American Meteorological Society, Vol. 78 (2). pp. 197-208.

[9] Sagan, C. and Chyba, C., 1997. The Early Faint Sun Paradox: Organic Shielding of Ultraviolet-Labile Greenhouse Gases. Science, 276 (5316), pp. 1217-1221.

[10] Mulholland, P., Wilde, S. P. R., 2020. An Iterative Mathematical Climate Model of the Atmosphere of Titan. Journal of Water Resources and Ocean Science. Vol. 9, No. 1, 2020, pp. 15-28. doi: 10.11648/j.wros.20200901.13.

[11] Beal, A., 2011. The Surface Area of a Sphere Between Parallel Planes. Online Blog. http://www.usrsb.in/The-Surface-Areaof-a-Sphere-Between-Parallel-Planes.html.

[12] Williams, D. R., 2019. Earth Fact Sheet. NASA NSSDCA, Mail Code 690.1, NASA Goddard Space Flight Center, Greenbelt, MD 20771.

[13] Rubin, M. J., 1953. Seasonal variations of the Antarctic tropopause. Journal of Meteorology, 10 (2), pp. 127-134.

[14] Australian Antarctic Division 2008: Dome Argus http://www.antarctica.gov.au/living-andworking/stations/other-locations/dome-a.

[15] Mulholland, P., 2019a. Earth Adiabatic Parallel Model 20Jun19 Excel Workbook. Research Gate Project: DynamicAtmosphere Energy-Transport Climate Model. 
[16] Mulholland, P., 2019b. Earth Adiabatic PVT Model 20Jun19 Excel Workbook. Research Gate Project: DynamicAtmosphere Energy-Transport Climate Model.

[17] Robinson, T. D. and Catling, D. C., 2014. Common 0.1 bar tropopause in thick atmospheres set by pressure-dependent infrared transparency. Nature Geoscience, 7 (1), pp. 12-15.

[18] American Vacuum Society (AVS) Atmospheric Pressure at Different Altitudes https://www.avs.org/AVS/files/c7/c7edaedb-95b2-438f-adfb36de54f87b9e.pdf.

[19] Wanucha, G. 2014. The missing piece of the climate puzzle.
MIT News http://news.mit.edu/2014/global-warmingincreased-solar-radiation-1110.

[20] Damadeo, K. and Hanson, H. 2017. CERES Clouds and the Earth's Radiant Energy System. NASA 9pp.

[21] Hunt, B. G., 1979. The Influence of the Earth's Rotation Rate on the General Circulation of the Atmosphere. Journal of the Atmospheric Sciences, Vol. 36 (8), 1392-1408.

[22] Del Genio, A. D. and Suozzo, R. J., 1987. A Comparative Study of Rapidly and Slowly Rotating Dynamical Regimes in a Terrestrial General Circulation Model. Journal of the Atmospheric Sciences, Vol. 44 (6), 973-986. 